\title{
Frost flowers and sea-salt aerosols over seasonal sea-ice areas in northwestern Greenland during winter-spring
}

\author{
Keiichiro Hara ${ }^{1}$, Sumito Matoba ${ }^{2}$, Motohiro Hirabayashi ${ }^{3}$, and Tetsuhide Yamasaki ${ }^{4}$ \\ ${ }^{1}$ Department of Earth System Science, Faculty of Science, Fukuoka University, Fukoka, Japan \\ ${ }^{2}$ Institute of Low Temperature Science, Hokkaido University, Hokkaido, Japan \\ ${ }^{3}$ National Institute of Polar Research, Tokyo, Japan \\ ${ }^{4}$ Avangnaq, Osaka, Japan \\ Correspondence to: Keiichiro Hara (harakei@fukuoka-u.ac.jp)
}

Received: 5 December 2016 - Discussion started: 13 December 2016

Revised: 10 May 2017 - Accepted: 4 June 2017 - Published: 14 July 2017

\begin{abstract}
Sea salts and halogens in aerosols, frost flowers, and brine play an important role in atmospheric chemistry in polar regions. Simultaneous sampling and observations of frost flowers, brine, and aerosol particles were conducted around Siorapaluk in northwestern Greenland during December 2013 to March 2014. Results show that watersoluble frost flower and brine components are sea-salt components (e.g., $\mathrm{Na}^{+}, \mathrm{Cl}^{-}, \mathrm{Mg}^{2+}, \mathrm{K}^{+}, \mathrm{Ca}^{2+}, \mathrm{Br}^{-}$, and iodine). Concentration factors of sea-salt components of frost flowers and brine relative to seawater were 1.14-3.67. Sea-salt enrichment of $\mathrm{Mg}^{2+}, \mathrm{K}^{+}, \mathrm{Ca}^{2+}$, and halogens $\left(\mathrm{Cl}^{-}, \mathrm{Br}^{-}\right.$, and iodine) in frost flowers is associated with sea-salt fractionation by precipitation of mirabilite and hydrohalite. High aerosol number concentrations correspond to the occurrence of higher abundance of sea-salt particles in both coarse and fine modes, and blowing snow and strong winds. Aerosol number concentrations, particularly in coarse mode, are increased considerably by release from the sea-ice surface under strong wind conditions. Sulfate depletion by sea-salt fractionation was found to be limited in sea-salt aerosols because of the presence of non-sea-salt (NSS) $\mathrm{SO}_{4}^{2-}$. However, coarse and fine sea-salt particles were found to be rich in $\mathrm{Mg}$. Strong $\mathrm{Mg}$ enrichment might be more likely to proceed in fine seasalt particles. Magnesium-rich sea-salt particles might be released from the surface of snow and slush layer (brine) on sea ice and frost flowers. Mirabilite-like and ikaite-like particles were identified only in aerosol samples collected near new sea-ice areas. From the field evidence and results from earlier studies, we propose and describe sea-salt cycles in seasonal sea-ice areas.
\end{abstract}

\section{Introduction}

Frost flowers on sea ice are ice crystals that contain brine and sea salts. They appear often during winter-spring on the surface of new and young sea ice in polar regions. Frost flowers play an important role as an interface among the atmosphere, sea ice, and ocean. Key conditions for formation and growth of frost flowers are (1) a cold atmosphere (below $-15^{\circ} \mathrm{C}$ ) and (2) weak-calm winds (Perovich and RichterMenge, 1994; Martin et al., 1995, 1996; Style and Worster, 2009; Roscoe et al., 2011). Vertical gradients of temperature and relative humidity near the sea-ice surface are crucially important for the appearance of frost flowers. Frost flowers can be formed by condensation of water vapor on nodules on new and young sea ice. Results of earlier studies (e.g., Domine et al., 2005; Douglas et al., 2012) show that water vapor is initially supplied to the atmosphere with sublimation or evaporation occurring from the warm sea-ice surface. Strong vertical gradients of air temperature above the sea-ice surface engender supersaturation of water vapor near the seaice surface; the gradients then induce condensation of water vapor (i.e., frost flower formation). The concentrated seawater (i.e., brine) is present on new and young sea ice. Consequently, brine with high salinity migrates upwardly and gradually on frost flowers (Perovich and Richter-Menge, 1994; Martin et al., 1996; Roscoe et al., 2011). Under cold conditions, solutes with lower solubility in brine can be precipitated in and on sea ice and frost flowers depending on the temperature. Earlier investigations (e.g., Marion, 1999; Koop et al., 2000; Dieckmann et al., 2008, 2010; Geilfus 
et al., 2013) have revealed that several salts can be precipitated at $-2.2{ }^{\circ} \mathrm{C}$ (ikaite, $\mathrm{CaCO}_{3} \cdot 2 \mathrm{H}_{2} \mathrm{O}$ ),$-8.2{ }^{\circ} \mathrm{C}$ (mirabilite, $\mathrm{Na}_{2} \mathrm{SO}_{4} \cdot 10 \mathrm{H}_{2} \mathrm{O}$ ), $-15^{\circ} \mathrm{C}$ (gypsum, $\mathrm{CaSO}_{4}$ ), $-22.9^{\circ} \mathrm{C}$ (hydrohalite, $\left.\mathrm{NaCl} \cdot 2 \mathrm{H}_{2} \mathrm{O}\right),-28^{\circ} \mathrm{C}\left(\mathrm{NaBr} \cdot 5 \mathrm{H}_{2} \mathrm{O}\right),-33^{\circ} \mathrm{C}$ (sylvite, $\mathrm{KCl}),-36^{\circ} \mathrm{C}\left(\mathrm{MgCl}_{2} \cdot 12 \mathrm{H}_{2} \mathrm{O}\right)$, and $-53.8^{\circ} \mathrm{C}$ (antarcticite, $\mathrm{CaCl}_{2} \cdot 6 \mathrm{H}_{2} \mathrm{O}$ ). The salt precipitation occurring here at lower temperatures causes changes to sea-salt ratios in brine and frost flowers, known as sea-salt fractionation. In fact, early works have shown that sea-salt ratios in frost flowers differed from those in brine and seawater (Rankin et al., 2000, 2002; Alvarez-Aviles et al., 2008; Douglas et al., 2012). It has been suggested that salt precipitation occurs in brine, because sea-salt ratios cannot be changed during seasalt fractionation on frost flowers.

Frost flowers have a fine structure. Earlier field and laboratory experiments indicated frost flowers as less fragile, even under strong winds, in spite of their fine structure (Obbard et al., 2009; Roscoe et al., 2011). In addition, results of model studies have implied that blowing snow contributes importantly to atmospheric halogen chemistry (Yang et al., 2010; Abbatt et al., 2012; Lieb-Lappen and Obbard, 2015). Because of the lower number density of aerosol particles in polar regions, especially in Antarctic regions, emission of sea-salt particles from sea-ice areas is an important aerosol source during winter-spring (e.g., Wagenbach et al., 1998; Rankin et al., 2000; Hara et al., 2004, 2011, 2012, 2013). In fact, sea-salt particles released from sea-ice areas are dispersed from the boundary layer to the free troposphere (up to ca. $4 \mathrm{~km}$ ) over Syowa Station, Antarctica, through vertical motion by cyclone activity (Hara et al., 2014), and into the interior (Dome F Station and Concordia Station) of the Antarctic continent (Hara et al., 2004; Udisti et al., 2012). Vertical transport of the sea-salt particles originating from sea ice can act as a supply of cloud condensation nuclei $(\mathrm{CCN})$ and ice nuclei (IN) in the upper boundary layer-free troposphere (Twohy and Poellet, 2005; Wise et al., 2012; DeMott et al., 2016). Because of the horizontal transport of sea-salt particles into the Antarctic Plateau, $\mathrm{Na}^{+}$records in ice cores taken in the inland area have been used recently as a proxy of the sea-ice extent (e.g., Wolff et al., 2003, 2006).

As described above, sea-salt fractionation proceeds on new and young sea ice. For that reason, sea-salt ratios in sea-salt particles (or aerosols) released from sea-ice areas differ from those of the bulk seawater ratio (Hara et al., 2012, 2013). For instance, a remarkable amount of Mg-rich sea-salt particles and aerosol particles containing $\mathrm{MgCl}_{2}$ and $\mathrm{MgSO}_{4}$ were identified at Syowa Station during winter-spring because precipitation of mirabilite and hydrohalite engenders Mg enrichment in sea-salt particles (Hara et al., 2012, 2013). Because the relative humidity of $\mathrm{Mg}$-salt deliquescence, such as that of $\mathrm{MgCl}_{2}$, is lower than that of $\mathrm{NaCl}$ (e.g., Kelly and Wexler, 2005), sea-salt fractionation can engender modification of aerosol hygroscopicity, which is closely related to phase transformation, heterogeneous reactions, and abilities to act as cloud condensation nuclei and ice nuclei. Accord- ing to results of laboratory experiments conducted by Koop et al. (2000), $\mathrm{Br}^{-}$can be enriched in frost flowers by sea-salt fractionation. Reportedly, $\mathrm{Br}^{-}$enrichment occurs slightly in frost flowers in the Weddell Sea, Antarctica (Rankin et al., 2002). Limited $\mathrm{Br}^{-}$enrichment to $\mathrm{Na}^{+}$has also been observed in a few samples collected at Barrow, Alaska, although no $\mathrm{Br}^{-}$enrichment was detected in samples of frost flowers and brine (Douglas et al., 2012). Additionally, results of some earlier studies have described non-significant $\mathrm{Br}^{-}$enrichment in frost flowers at Barrow and Hudson Bay (Alvarez-Aviles et al., 2008; Obbard et al., 2009). Therefore, many issues remain with respect to the sea-salt and halogen chemistry of aerosols and frost flowers. They demand further measurement results and discussion. In addition to seasalt fractionation, sea-salt ratios in frost flowers and aerosols can be altered gradually by heterogeneous reactions in a process known as sea-salt modification. Furthermore, frost flowers have large specific surface areas: $63-299 \mathrm{~cm}^{2} \mathrm{~g}^{-1}$ (mean, $162 \mathrm{~cm}^{2} \mathrm{~g}^{-1}$ ) at Hudson Bay, Canada (Obbard et al., 2009) and $185(+80,-50) \mathrm{cm}^{2} \mathrm{~g}^{-1}$ at Barrow, Alaska (Domine et al., 2005). Because of their larger surface areas, earlier studies have assessed the potential of frost flowers for use as reaction sites (e.g., Kaleschke et al., 2004, references in Abbatt et al., 2012). Sea-salt modification in sea-salt aerosols, and sea salts in and on frost flowers and sea ice can act as potential sources of gaseous reactive species. For instance, gaseous reactive halogen species (e.g., $\mathrm{Br}_{2}, \mathrm{HOBr}, \mathrm{Br}$, and $\mathrm{BrO}$ ) induce depletion of ozone and mercury near the surface in both polar regions during the polar sunrise (Barrie et al., 1988; Schroeder et al., 1998; Foster et al., 2001; Ebinghaus et al., 2002).

To elucidate the atmospheric impact of fractionated seasalt particles and their relationship with sea-salt particles in the atmosphere and frost flowers on sea ice, one must ascertain (1) the chemical properties (e.g., concentrations, ratios, and $\mathrm{pH}$ ) of frost flowers and brine, and (2) the physical and chemical properties of aerosols (e.g., size distribution, components, and mixing states) above seasonal sea ice with frost flowers. Despite their importance, simultaneous observations and measurements of aerosols and frost flowers over seasonal ice areas with known frost flower occurrences have not been reported for polar regions, although sampling and observations of frost flowers have been conducted in the Arctic (e.g., Alvaraz-Aviles et al., 2008; Douglas et al., 2012) and Antarctic (Rankin and Wolff, 2000; Rankin et al., 2002). Using data from simultaneous measurements and sampling of aerosols, frost flowers, and brine around northwestern Greenland during winter-spring, this study was conducted to elucidate seasalt cycles in seasonal sea-ice areas and related phenomena, such as sea-salt fractionation on the sea-ice surface including frost flowers, brine, and snow, their aging processes, and the release of fractionated sea-salt particles into the atmosphere. 


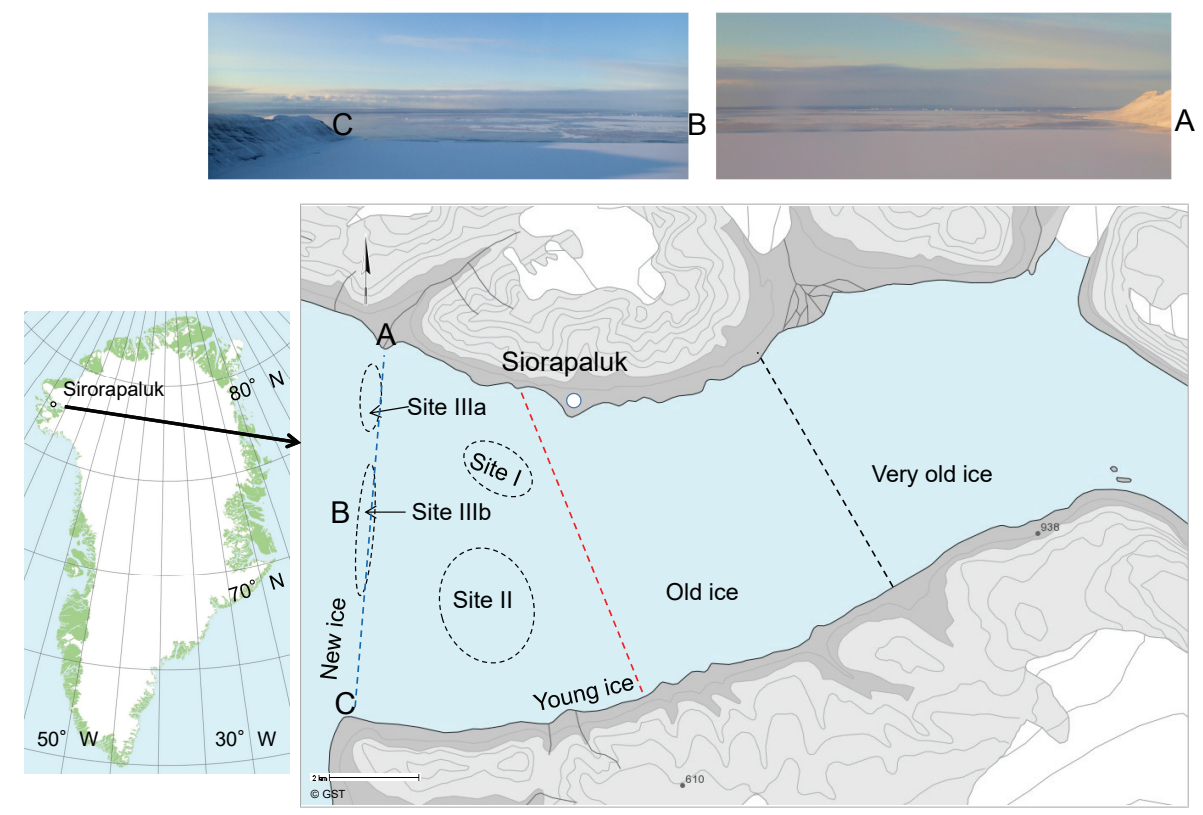

Figure 1. Locations of sampling and sea-ice conditions around Siorapaluk and photographs of new sea-ice conditions off Siorapaluk (taken from helicopter on 7 March 2014). Black, red, and blue dashed lines show locations of sea-ice break in November, 2013, and on 1014 February 2014 and 1 March 2014, respectively. The letters A, B, and C illustrate the general locations in the corresponding maps and photographs.

\section{Samples and analysis}

\subsection{Sampling sites and conditions}

Figure 1 shows the locations where simultaneous observations of frost flowers, brine, seawater, and aerosols were made on a new and young sea-ice area in Robertson fjord near Siorapaluk in northwestern Greenland from midDecember 2013 through mid-March 2014. In the fjord, the open sea surface appears during summer. Sea ice formed gradually from October 2013 in the fjord. Sea ice flowed out several times from the fjord by the action of sea tides, heaving, and strong winds (Fig. 1) before and during the measurements taken for this study. Moreover, sea ice with different ages was present in the fjord because the locations of sea-ice breaks differed in each case, as presented in Fig. 1. For the present study, we define sea-ice ages in the fjord as new, young, old, and very old, depending on the sea-ice age. We chose sites I-III (new-young sea ice; less than $1 \mathrm{~cm}$ to ca. $35 \mathrm{~cm}$ thickness) as sampling sites of aerosols, frost flowers, brine, and seawater. Site I was approximately $2 \mathrm{~km}$ distant from Siorapaluk. The sea ice on site I flowed during 10-12 February 2014 (shown as a red dashed line); then it refroze. Several days to a week prior (approximately midFebruary), an open lead appeared around site II. Thereafter, new sea ice was formed. The refrozen lead width was 2 $6 \mathrm{~m}$ near sampling sites. The sea surface appeared off Siorapaluk on approximately 1 March from sea-ice breakage and strong winds (shown as a blue dashed line). Then, new sea ice formed again (photographs, Fig. 1). On 3 and 5 March, we traversed the new sea-ice area (blue dashed line in Fig. 1) to observe the sea-ice conditions and the appearance of frost flowers on the sea ice. Then, we chose sampling sites (IIIa and IIIb) that were safely accessible. The new sea ice at sites IIIa and IIIb (less than $1 \mathrm{~cm}$ thickness) was a few days old. We accessed sampling sites with frost flowers on foot and by dog sledge from Siorapaluk.

\subsection{Sampling of frost flowers, brine, snow, and seawater}

Sampling of frost flowers, brine (slush), and seawater was conducted from 20 February 2014 through 3 March 2014 on sea ice near Siorapaluk. Frost flowers were taken from the sea-ice surface using a clean stainless steel shovel. During the campaign, snowfall and blowing snow occurred occasionally. On the frost flower and slush layer at sites I and II, snow was present, slightly, to the extent to that the fine structure of frost flowers was identified clearly. All bodies of the frost flowers above the sea-ice surface were collected if the forms of frost flowers were mature and dry. Young frost flowers were collected if the frost flowers were also coated with brine water. When snow was present on the frost flower and slush layer, some frost flower samples can contain slightly snowy pieces because of the difficulty of separation. Brine samples were collected by shaving off a thin layer of the sea-ice surface, and coating the brine water in proximity to the frost flowers. With the exception of new sea ice at site 
III with thicknesses of a few centimeters, slush was sampled on sea ice where frost flowers formed. Because it was difficult to collect only brine from the slush layer, the slush layer was sampled as "brine samples" in this study. Snow on sea ice was also taken using a clean stainless steel shovel from the location with snow accumulation $(<3 \mathrm{~cm}$ depth) without frost flowers at sites I and II. Pieces of frost flowers, brine (slush) samples, and snow were moved into individual polyethylene bag (Whirl-pak; Nasco). Using a dropper, seawater samples were collected in polypropylene bottles from a crack in the sea ice or through a hole we made in the sea ice. All samples were melted at ambient temperature. The $\mathrm{H}^{+}$ concentration (i.e., $\mathrm{pH}$ ) of the liquid sample was measured using a portable $\mathrm{pH}$ meter (B-212; Horiba Instruments Ltd.). Then residue of the sample was transferred to polypropylene bottles. The samples in the bottles were kept in conditions below $-20^{\circ} \mathrm{C}$ in Greenland. Then, samples were unfrozen during transport (ca. 3 days) to our laboratory in Japan because of the difficulty of carrying frozen samples in an airplane. After the bottled liquid samples were transported to Japan, all were kept frozen in a cold room until chemical analyses were conducted.

\subsection{Aerosol sampling and measurements}

Aerosol measurements and direct sampling were conducted over seasonal sea ice around Siorapaluk, Greenland from 17 December 2013 through 7 March 2014. Aerosol number concentrations were measured at flow rate of $2.83 \mathrm{~L} \mathrm{~min}^{-1}$ using a portable optical particle counter (OPC, KR12A; Rion Co. Ltd.). The measurable size range was $D_{\mathrm{p}}>0.3,>0.5$, $>0.7,>1.0,>2.0$, and $>5.0 \mu \mathrm{m}$. The OPC packed in an insulator box was set at ca. $1 \mathrm{~m}$ above the sea-ice surface using a tripod. Aerosol number concentrations were recorded every $23-25 \mathrm{~s}$, corresponding to $1 \mathrm{~L}$ of air volume, during direct aerosol sampling. Details of OPC measurements were presented by Hara et al. (2014).

Direct aerosol sampling was done using a two-stage aerosol impactor. Carbon-coated collodion thin films supported by a Ni micro-grid (square 300 mesh; Veco Co.) were used as sample substrates in this study. The cut-off diameters (aerodynamic diameter) of the impactor were 2.0 and $0.2 \mu \mathrm{m}$ at a flow rate of ca. $1.2 \mathrm{~L} \mathrm{~min}^{-1}$. The impactor was set at ca. $1 \mathrm{~m}$ above the seasonal sea-ice surface, similarly to OPC measurement. Direct aerosol sampling was conducted for 10-15 min depending on the aerosol number concentration. Aerosol samples were kept in polyethylene capsules immediately after aerosol measurements and sampling. The polyethylene capsules with aerosol samples were packed into polyethylene zipper bags. All bags with aerosol samples were put into an airtight box together with a desiccant (NissoDry M; Nisso Fine Co., Ltd.) until analysis at room temperature to prevent humidification that can engender morphological change and efficient chemical reactions, as described by Hara et al. (2002, 2005, 2013, 2014). All aerosol samples de- scribed as a result of this study were analyzed and observed within 1 year of sampling.

Meteorological data (air temperature, relative humidity, air pressure, wind direction, and wind speed) were measured using an automatic weather station (AWS; HOBO U30-NRC Weather Station, Onset Computer Corp.), which was set on the coast near Siorapaluk and ca. $1 \mathrm{~km}$ away from the village. Meteorological data were recorded on the data logger of the automatic weather station with time resolution of $5 \mathrm{~min}$. A Thermo Recorder (TR-7Wf; T and D Corp.) and thermosensor (TR1106; T and D Corp.) were used for measurements of the temperatures of seawater, slush layer (brine) on sea ice, base of frost flowers on the slush layer, and in the atmosphere above the top of the frost flowers.

\subsection{Sample analysis}

\subsubsection{Analysis of frost flower, brine, snow, and seawater}

Re-frozen samples of frost flower, brine, snow, and seawater were melted at ambient temperature before chemical analysis. Concentrations of ion species $\left(\mathrm{Na}^{+}, \mathrm{K}^{+}, \mathrm{Mg}^{2+}, \mathrm{Ca}^{2+}\right.$, $\mathrm{Cl}^{-}, \mathrm{NO}_{3}^{-}$and $\mathrm{SO}_{4}^{2-}$ ) in frost flowers, brine, and seawater were measured using ion chromatography (ICS 2100; Thermo Fisher Scientific Inc.) after $10^{3}$-fold dilution by ultrapure water, whereas those in snow were determined without dilution. A guard column (IonPac CG12; Thermo Fisher Scientific Inc.), column (IonPac CS12; Thermo Fisher Scientific Inc.), and a $20 \mathrm{mM} \mathrm{CH}_{3} \mathrm{SO}_{3} \mathrm{H}$ eluent were used for the cation measurement, and a guard column (IonPac AG14; Thermo Fisher Scientific Inc.), column (IonPac AS14; Thermo Fisher Scientific Inc.), and $3.5 \mathrm{mM} \mathrm{NaOH}$ eluent were used for anion measurements. Concentrations of $\mathrm{Br}^{-}$in frost flowers and brine were measured using an ion chromatograph-mass spectrometer (IC-MS) after $10^{6}$ fold dilution using ultrapure water. Ionic contents in samples were separated using ion chromatography with a guard column (IonPac AG11-HC; Thermo Fisher Scientific Inc.), a column (IonPac AS11-HC; Thermo Fisher Scientific Inc.), and gradient $\mathrm{KOH}$ eluent $(4-36 \mathrm{mM})$, and were injected into a mass spectrometer (6100 series single quadrupole LC/MS; Agilent Technologies Inc.). The detection limit of $\mathrm{Br}^{-}$in ICMS was $0.9 \mathrm{ng} \mathrm{L}^{-1}$. Iodine concentrations in frost flowers and brine were measured after $10^{3}$-fold dilution using ultrapure water with an inductively coupled plasma mass spectrometer (ICP-MS, 7700 series single quadrupole ICP-MS; Agilent Technologies Inc.). The radio frequency (RF) power and flow of carrier Ar gas were, respectively, $1550 \mathrm{~W}$ and $0.80 \mathrm{~L} \mathrm{~min}^{-1}$ in ICP-MS analysis. The detection limit of iodine used for this study was $17 \mathrm{ng}^{-1}$. Samples of frost flowers and brine were injected into ICP-MS after melting. Because ICP-MS can provide only the elemental concentrations in samples, iodide $\left(\mathrm{I}^{-}\right)$, and iodate $\left(\mathrm{IO}_{3}^{-}\right)$were not separated in this study. Details of IC-MS analytical procedures are described elsewhere by Motohiro Hirabayashi (personal 


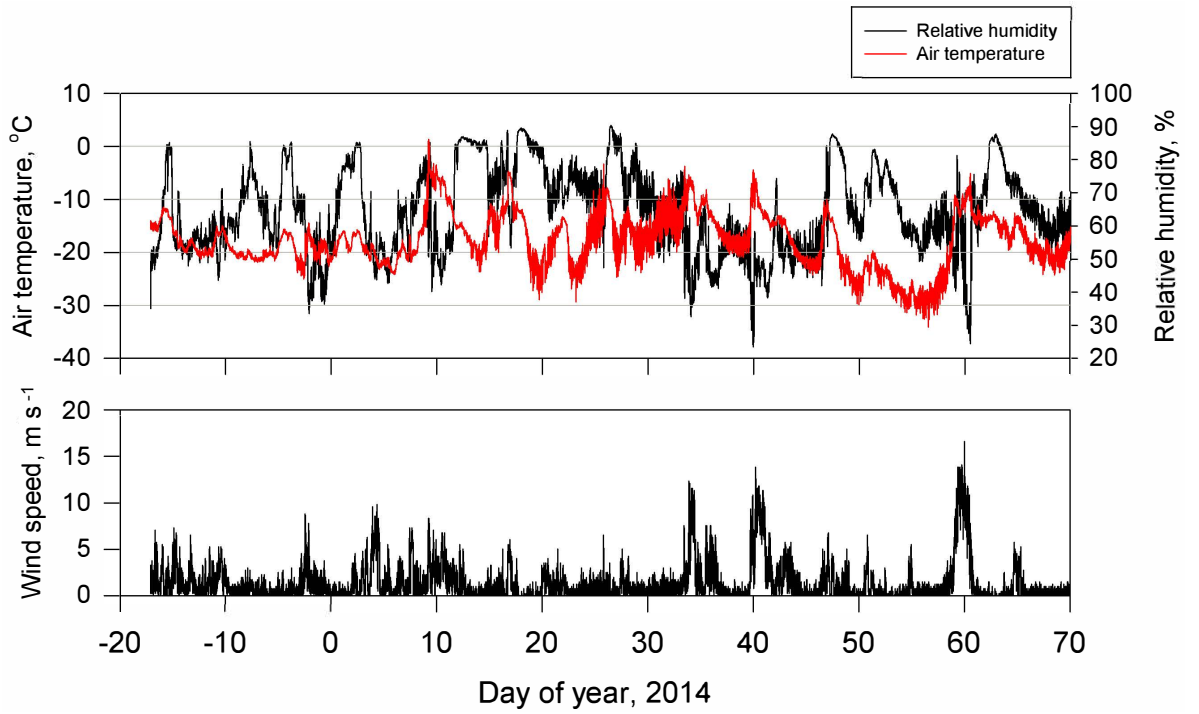

Figure 2. Variation of air temperature, relative humidity, and wind speed at Siorapaluk.

communication, 2017). We calculated concentration factors (CF-X) with molar concentrations of chemical species (X) in samples divided by the concentration of $\mathrm{X}$ in seawater taken at Siorapaluk to evaluate the concentration processes of the chemical species during the formation and aging of frost flowers. Analytical errors of respective analytical methods were estimated from the reproducibility of determination of standard solutions with concentrations similar to those of the field samples.

\subsubsection{Analysis of individual aerosol particles}

Individual aerosol particles on the sample substrate were observed and analyzed for this study using a scanning electron microscope equipped with an energy-dispersive X-ray spectrometer (SEM-EDX, Quanta FEG-200F, FEI, XL30; EDAX Inc.). The analytical conditions were $20 \mathrm{kV}$ accelerating voltage and $30 \mathrm{~s}$ counting time. Details of analytical procedures were described by Hara et al. $(2013,2014)$. We analyzed 1261 particles in coarse mode (mean, 41 particles per sample) and 6337 particles in fine mode (mean, 192 particles per sample). In this study, most aerosol-sampled areas on the substrates were analyzed in coarse mode. Although we attempted to analyze as many coarse particles as possible, the lower aerosol number concentrations in coarse mode limit the number of the aerosol particles analyzed in this study.

\section{Results}

\subsection{Meteorological conditions during the campaign}

Figure 2 depicts time variations of air temperature, relative humidity, and wind speed during our measurement period. The air temperature was -34.2 to $+1.8^{\circ} \mathrm{C}$. Conditions be- low $-20^{\circ} \mathrm{C}$ occurred on days of year (DOY) 47.5-58.6 (1728 February 2014) during our intensive sampling and observations of aerosols and frost flowers. Because of an approaching cyclone, several strong wind events occurred during the campaign. Particularly strong winds on DOY 39.741.2 (9-11 February) caused breaks and outflows of sea ice from the front of Siorapaluk (ca. $1 \mathrm{~km}$ distant). Then the seawater started refreezing immediately after the weather calmed. Sea ice off Siorapaluk (ca. 5-6 km distant) broke and flowed out again off Siorapaluk due to storm conditions on DOY 58.9-60.3 (28 February-1 March). Sea ice formed after normal weather conditions returned. Frost flowers appeared on the new sea ice in both cases.

\subsection{Conditions of frost flowers and sea ice}

Sea ice conditions where frost flowers formed can be categorized as three types for this study: young ice (site I), younger ice in refrozen leads between young ice (site II), and new sea ice (sites IIIa and IIIb). Figure 3 depicts photographs of frost flowers observed at site I, categorized as young ice (Fig. 3a) on 20 February. The sea-ice surface was partly covered with thin snow. Frost flowers were formed patchily on the ice surface with little or no snow cover. The sea-ice surface underneath frost flowers was wetted by brine (sherbetlike, i.e., slush layer). Figure $3 \mathrm{~b}$ presents a close-up photograph of frost flowers observed on 22 February at the same site as that observed on 20 February. Salt crystals deposited on the branches of frost flower crystals were identified. Frost flowers at site I were covered completely with snow after the storm on 28 February-1 March. Figure 3c shows frost flowers observed at site II (Fig. 1). The sea-ice surface underneath frost flowers was wetted by brine. Figure $3 \mathrm{~d}$ shows frost flowers observed at site IIIa (Fig. 1) on 4 March. The 


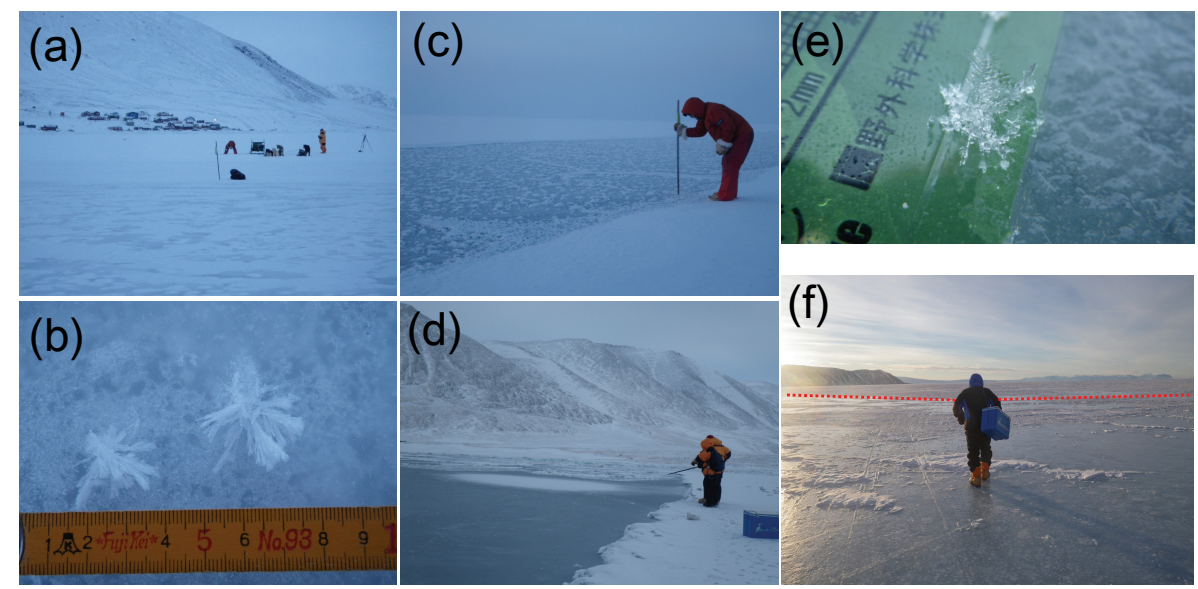

Figure 3. Photographs of (a) sea-ice and frost flower conditions on 20 February at site I, (b) frost flowers at site I on 22 February, (c) frost flowers at site II, (d) sea-ice conditions at site IIIa, (e) frost flowers on 4 March at site IIIa, and (f) old sea-ice conditions on 2 March immediately after the storm. Red dotted lines indicate approximate location of margin between old sea ice and young sea ice.
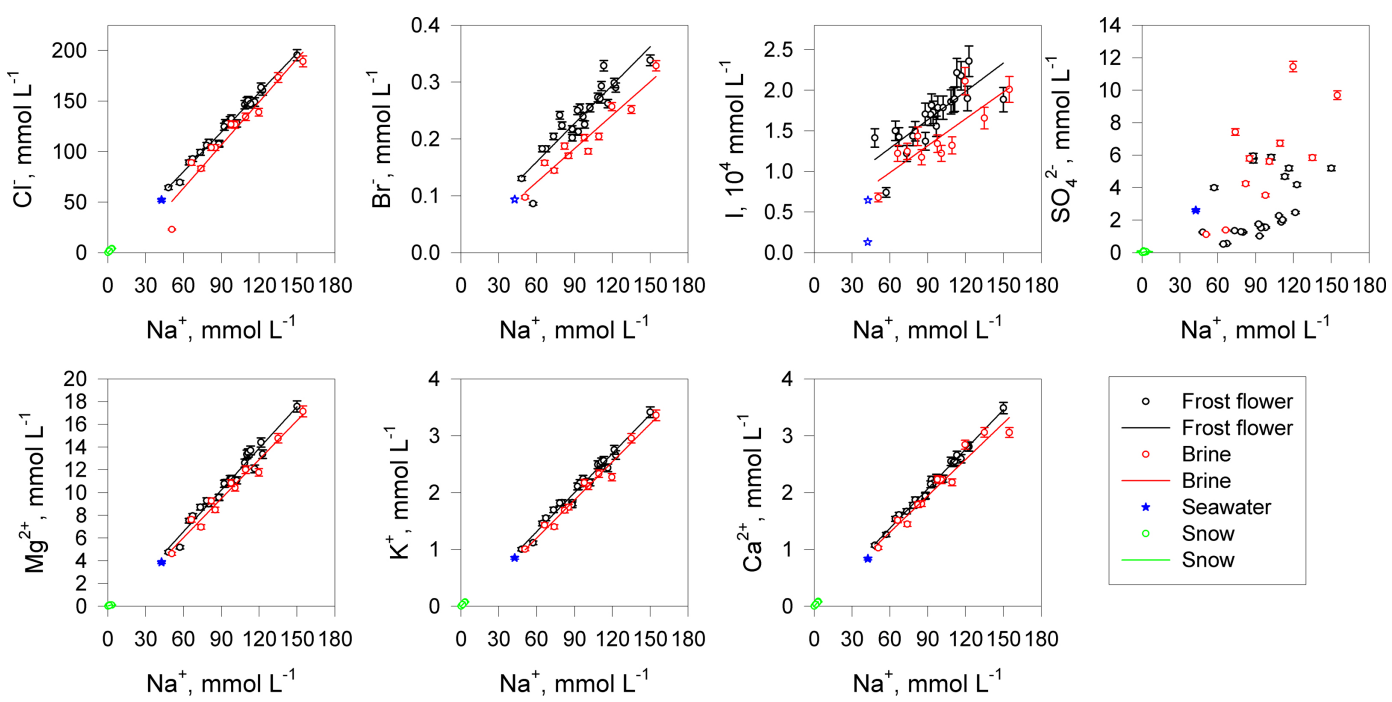

Figure 4. Relationship among each component with $\mathrm{Na}^{+}$concentrations of frost flowers, brine, and seawater taken in this study. Black and red lines respectively present regression lines of frost flowers and brine. Open black and red circles respectively present concentrations in frost flowers and brine. Filled blue stars represent the concentrations of seawater taken around Siorapaluk. Open blue stars represent the concentrations of seawater in the literature presented in Table 1. Error bars indicate standard deviation $(1 \sigma)$ of analytical errors.

site was at the edge of sea ice, close to open water. The frost flower diameter was approximately $5 \mathrm{~mm}$. The sea-ice surface was covered with brine water (Fig. 3e). The frost flower crystals were partially submerged in the brine water. During our campaign (December 2013 to March 2014), frost flowers were absent on old and very old sea ice. Although snow covered dry surface of old and very old sea ice patchily before the storm, bare sea ice without a slush layer was apparent after the storm (Fig. 3f).

\subsection{Concentrations of sea salts in frost flowers, brine, seawater, and snow on sea ice}

Figure 4 depicts relationships among the respective components of frost flowers, brine, snow, and seawater found in this study. Logarithmic plots of Fig. 4 are shown in Fig. S1. Concentrations of $\mathrm{Na}^{+}$in frost flowers and brine were 48 $154 \mathrm{mmol} \mathrm{L}^{-1}$, which greatly exceeded the concentration of seawater collected at Siorapaluk $\left(\mathrm{Na}^{+}, 42.5 \mathrm{mmol} \mathrm{L}^{-1}\right)$. The ratios of $\mathrm{Cl}^{-} / \mathrm{Na}^{+}$in seawater collected at Siorapaluk were similar to ratios reported in the literature (e.g., Lide, 2005; Millero et al., 2008), although the $\mathrm{SO}_{4}^{2-} / \mathrm{Na}^{+}$ratio at Siorapaluk was similar to the ratio in Millero et al. (2008) and 
slightly higher than the ratios in Lide (2005), as shown in Fig. S2. Moreover, the ratios of $\mathrm{K}^{+} / \mathrm{Na}^{+}$and $\mathrm{Ca}^{2+} / \mathrm{Na}^{+}$ in seawater at Siorapaluk were slightly lower (by ca. $20 \%$ ) than those of the literature values. Differences among the ratios found at Siorapaluk and those of the literature (e.g., Lide, 2005; Millero et al., 2008) were larger than our analytical errors (less than 5-6\%), as estimated from the reproducibility of the determination of standard samples with concentrations similar to those of the analyzed samples of frost flowers, brine, and snow. In this study, seawater ratios at Siorapaluk were used in the following analysis and discussion except for $\mathrm{Br}^{-}$and I, which were referred from earlier reports (e.g., Lide, 2005; Millero et al., 2008; Millero, 2016).

The concentration factors of $\mathrm{Na}^{+}\left(\mathrm{CF}_{\mathrm{Na}}\right)$ in frost flowers and brine were $1.14-3.67$, which roughly approximated the results reported in previous studies (e.g., Rankin et al., 2002; Alvarez-Aviles et al., 2008). By contrast, the $\mathrm{Na}^{+}$concentrations in snow samples collected on sea ice were 1-2 orders lower than that of seawater. The $\mathrm{Na}^{+}$concentrations of fresh snow on sea ice were lower than $0.1 \mathrm{mmol} \mathrm{L}^{-1}$. By contrast, $\mathrm{Na}^{+}$concentrations were $0.4-3.2 \mathrm{mmol} \mathrm{L}^{-1}$ in the aged snow on sea ice. High correlation among components was identified in frost flowers, brine, and snow, as shown below.

Frost flowers:

$$
\begin{aligned}
& {\left[\mathrm{Cl}^{-}\right]=1.302\left[\mathrm{Na}^{+}\right]+2.158\left(R^{2}=0.969\right)} \\
& {\left[\mathrm{Br}^{-}\right]=0.0022\left[\mathrm{Na}^{+}\right]+0.025\left(R^{2}=0.910\right)} \\
& {[\mathrm{I}]=1.17 \times 10^{-6}\left[\mathrm{Na}^{+}\right]+5.867 \times 10^{-4}\left(R^{2}=0.791\right)} \\
& {\left[\mathrm{Mg}^{2+}\right]=0.122\left[\mathrm{Na}^{+}\right]-0.761\left(R^{2}=0.982\right)} \\
& {\left[\mathrm{K}^{+}\right]=0.023\left[\mathrm{Na}^{+}\right]-0.063\left(R^{2}=0.988\right)} \\
& {\left[\mathrm{Ca}^{2+}\right]=0.023\left[\mathrm{Na}^{+}\right]-0.019\left(R^{2}=0.996\right)}
\end{aligned}
$$

Brine:

$$
\begin{aligned}
& {\left[\mathrm{Cl}^{-}\right]=1.421\left[\mathrm{Na}^{+}\right]-21.35\left(R^{2}=0.964\right)} \\
& {\left[\mathrm{Br}^{-}\right]=0.0020\left[\mathrm{Na}^{+}\right]+0.06\left(R^{2}=0.962\right)} \\
& {[\mathrm{I}]=1.10 \times 10^{-6}\left[\mathrm{Na}^{+}\right]+3.25 \times 10^{-5}\left(R^{2}=0.842\right)} \\
& {\left[\mathrm{Mg}^{2+}\right]=0.114\left[\mathrm{Na}^{+}\right]-0.8267\left(R^{2}=0.982\right)} \\
& {\left[\mathrm{K}^{+}\right]=0.022\left[\mathrm{Na}^{+}\right]-0.140\left(R^{2}=0.988\right)} \\
& {\left[\mathrm{Ca}^{2+}\right]=0.021\left[\mathrm{Na}^{+}\right]-0.023\left(R^{2}=0.972\right)}
\end{aligned}
$$

Snow:

$\left[\mathrm{Cl}^{-}\right]=1.315\left[\mathrm{Na}^{+}\right]+0.02\left(R^{2}=0.972\right)$

$$
\left[\mathrm{Mg}^{2+}\right]=0.035\left[\mathrm{Na}^{+}\right]+0.02\left(R^{2}=0.751\right)
$$$$
\left[\mathrm{K}^{+}\right]=0.024\left[\mathrm{Na}^{+}\right]-0.002\left(R^{2}=0.997\right)
$$$$
\left[\mathrm{Ca}^{2+}\right]=0.026\left[\mathrm{Na}^{+}\right]+2 \times 10^{-5}\left(R^{2}=0.994\right)
$$

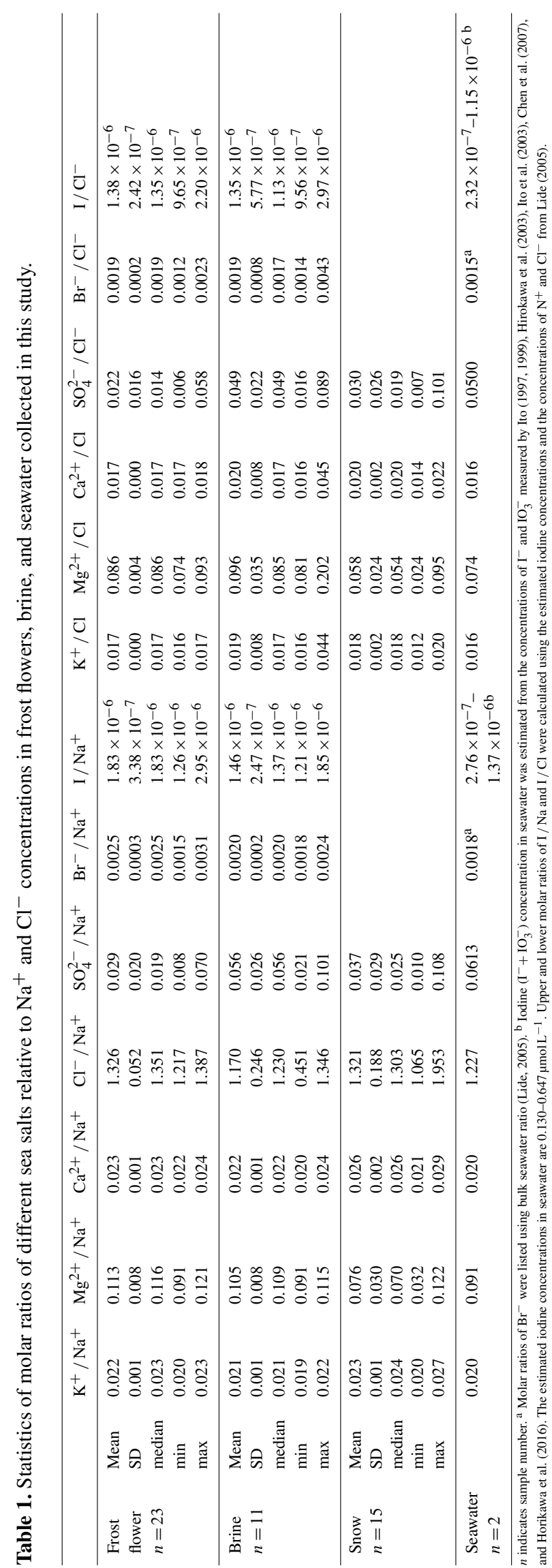

Atmos. Chem. Phys., 17, 8577-8598, 2017 
In this study, the $\mathrm{Br}^{-}$and I concentrations in the snow samples were not determined. High coefficients of determination imply strongly that these components are sea salts (derived from seawater). When the intercepts are close to zero, the slopes of the relationships might be close to the ambient molar ratios. Furthermore, the slopes of the relationships can be biased positively in the cases of contamination/mixing of NSS species such as minerals and anthropogenic species, which can be deposited onto surfaces of frost flowers, brine, and snow. In contrast, the ratios can be biased negatively in the cases of sea-salt fractionation on sea ice and depletion/release of the contents in frost flowers, brine, and snow into the atmosphere. The molar ratios in frost flowers, brine, and snow are presented in Table 1. With the exception of $\mathrm{Mg}^{2+} / \mathrm{Na}^{+}$in snow and $\mathrm{I} / \mathrm{Na}^{+}$in frost flowers and brine, the molar ratios conform to the slopes. The intercept values and the coefficients of determination in these ratios are, respectively, larger and smaller than the other ratios.

Higher slopes and molar ratios relative to $\mathrm{Na}^{+}$and considerable $\mathrm{SO}_{4}^{2-}$ depletion were observed clearly in frost flowers (Fig. 4). It is expected that this $\mathrm{SO}_{4}^{2-}$ depletion was caused by mirabilite precipitation. To evaluate the contribution of mirabilite precipitation to changes in the molar ratios in frost flowers, snow, and brine, sea-salt ratios relative to $\mathrm{Na}^{+}$after mirabilite precipitation were compared. Clear negative slopes (ca. -0.041) for molar concentrations were identified for the relationship between $\mathrm{Na}^{+}$and $\mathrm{NSS} \mathrm{SO}_{4}^{2-}$ (not shown), as discussed by Wagenbach et al. (1998) and Hara et al. (2004). The negative slope found in this study resembles the slope for sea-salt aerosols in Antarctica (e.g., Wagenbach et al., 1998; Hara et al., 2004). Sea-salt ratios relative to $\mathrm{Na}^{+}$ after mirabilite precipitation were estimated using the negative slope values $(R=-0.041)$. Assuming that mirabilite precipitation occurred only in sea-salt fractionation, the amount of the depleted $\mathrm{SO}_{4}^{2-}\left(\left[\mathrm{SO}_{4}^{2-}\right] \mathrm{SO}_{4}-\right.$ depleted $)$ and the concentration of $\mathrm{Na}^{+}\left(\left[\mathrm{Na}^{+}\right] \mathrm{SO}_{4}-\right.$ depleted $)$ after mirabilite precipitation were calculated using the $\mathrm{Na}^{+}$concentration in seawater or brine $\left(\left[\mathrm{Na}^{+}\right]_{\text {seawater }}\right)$ and the following equations.

$$
\begin{aligned}
& {\left[\mathrm{SO}_{4}^{2-}\right]_{\mathrm{SO}_{4}-\text { depleted }}=\left[\mathrm{Na}^{+}\right]_{\text {seawater }} \times R } \\
& {\left[\mathrm{Na}^{+}\right]_{\mathrm{SO}_{4}-\text { depleted }} } \\
= & {\left[\mathrm{Na}^{+}\right]_{\text {seawater }}-2 \times\left[\mathrm{SO}_{4}^{2-}\right]_{\mathrm{SO}_{4}-\text { depleted }} }
\end{aligned}
$$

Then, the sea-salt ratios after mirabilite precipitation were estimated as follows.

$$
\left(\frac{[\mathrm{X}]}{\left[\mathrm{Na}^{+}\right]}\right)_{\mathrm{SO}_{4}-\text { depleted }}=\frac{[\mathrm{X}]_{\text {seawater }}}{\left[\mathrm{Na}^{+}\right]_{\mathrm{SO}_{4}-\text { depleted }}}
$$

In Eq. (3), $[\mathrm{X}]_{\text {seawater }}$ denotes sea-salt concentrations in seawater or brine other than $\mathrm{Na}^{+}$and $\mathrm{SO}_{4}^{2-}$. The estimated ratios (i.e., $\mathrm{Cl}^{-} / \mathrm{Na}^{+}, 1.33 ; \mathrm{Mg}^{2+} / \mathrm{Na}^{+}, 0.099 ; \mathrm{K}^{+} / \mathrm{Na}^{+}$, $0.022 ; \mathrm{Ca}^{2+} / \mathrm{Na}^{+}, 0.021$ ) were consistent with the ambient molar ratios in frost flowers and snow samples. This coincidence strongly suggests that mirabilite precipitation causes a change in sea-salt ratios in frost flowers and brine.

In addition to mirabilite precipitation, hydrohalite precipitation can change the molar ratios in aerosols and frost flowers (e.g., Marion et al., 1999; Koop et al., 2000; Hara et al., 2012). Next, we attempted to compare the relationships of respective sea salts to $\mathrm{Cl}^{-}$and $\mathrm{Mg}^{2+}$ (Figs. S3-S5, in the Supplement) to understand sea-salt fractionation by precipitation of mirabilite and other salts, and distribution of the fractionated sea salts on sea ice. Relationships among $\mathrm{Mg}^{2+}, \mathrm{K}^{+}, \mathrm{Ca}^{2+}$, and $\mathrm{Cl}^{-}$in frost flowers well matched those in brine (Figs. S3-S4). The molar ratios to $\mathrm{Cl}^{-}$were not changed by mirabilite precipitation without $\mathrm{Cl}^{-}$loss by heterogeneous reactions. The relationships of sea salts implies that mirabilite precipitation made important contributions to the change in sea-salt ratios in frost flowers. Furthermore, Student $t$ tests were applied to assess differences in the molar ratios among frost flowers, brine, and snow (Table 2). The molar ratios relative to $\mathrm{Na}^{+}$in frost flowers were significantly higher than those in brine $(p<0.01)$, although $\mathrm{K}^{+} / \mathrm{Cl}^{-}, \mathrm{Mg}^{2+} / \mathrm{Cl}^{-}, \mathrm{Br}^{-} / \mathrm{Cl}^{-}$, and $\mathrm{I} / \mathrm{Cl}^{-}$were not significantly different $(p>0.1)$. When comparing frost flowers and snow, we found the ratios of $\mathrm{K}^{+}$and $\mathrm{Ca}^{2+}$ to $\mathrm{Na}^{+}$ and $\mathrm{Cl}^{-}$in frost flowers to be significantly lower than those in snow $(p<0.01)$. However, the ratios of $\mathrm{Mg}^{2+} / \mathrm{Na}^{+}$and $\mathrm{Mg}^{2+} / \mathrm{Cl}^{-}$in frost flowers were significantly higher than those in snow $(p<0.01)$. Differences between frost flowers and snow for $\mathrm{Cl}^{-} / \mathrm{Na}^{+}$(or $\left.\mathrm{Na}^{+} / \mathrm{Cl}^{-}\right), \mathrm{SO}_{4}^{2-} / \mathrm{Na}^{+}$, and $\mathrm{SO}_{4}^{2-} / \mathrm{Cl}^{-}$were not significant $(p>0.1)$. Although $\mathrm{K}^{+} / \mathrm{Na}^{+}$and $\mathrm{Ca}^{2+} / \mathrm{Na}^{+}$in snow were higher than those in brine, $\mathrm{Mg}^{2+} / \mathrm{Na}^{+}$and $\mathrm{Mg}^{2+} / \mathrm{Cl}^{-}$in snow were significantly lower than those in brine $(p<0.01)$. The $\mathrm{SO}_{4}^{2-} / \mathrm{Na}^{+}$ and $\mathrm{SO}_{4}^{2-} / \mathrm{Cl}^{-}$ratios in snow were slightly lower (though statistically significantly) than those in brine $(0.05<p<$ 0.1 ). Between snow and brine, the ratios of $\mathrm{Cl}^{-} / \mathrm{Na}^{+}$(or $\left.\mathrm{Na}^{+} / \mathrm{Cl}^{-}\right)$were not significantly different $(p>0.1)$. The statistical analysis indicated that distribution of the fractionated sea salts was highly heterogeneous in frost flowers, snow, and brine.

Figure 4 and Table 1 show that the molar ratios in frost flowers, brine, and snow differed among sampling sites, conditions such as temperature, and the age of frost flowers (details are discussed herein). The molar ratios in frost flowers resembled the ratios found by previous studies of frost flowers and aerosols (Rankin et al., 2002; Douglas et al., 2012; Hara et al., 2012). The $\mathrm{Br}^{-} / \mathrm{Na}^{+}$ratios found from previous investigations, however, differed considerably among frost flower sampling sites (Rankin et al., 2002; AlvarezAviles et al., 2008; Douglass et al., 2012). $\mathrm{Br}^{-}$enrichment in frost flowers was observed in this study, and in previous studies conducted in the Weddell Sea, Antarctica, by Rankin et al. (2002), although Alvarez-Aviles et al. (2008) and Obbard et al. (2009) reported that $\mathrm{Br}^{-}$was not enriched in frost 
Table 2. Results of $t$ test of the molar ratios of sea-salt components among frost flowers, brine, and snow.

\begin{tabular}{|c|c|c|c|c|c|c|c|}
\hline & \multicolumn{7}{|c|}{ Frost flowers-brine $^{\mathrm{a}}$} \\
\hline Ratios & $\mathrm{Cl}^{-} / \mathrm{Na}^{+}$ & $\mathrm{K}^{+} / \mathrm{Na}^{+}$ & $\mathrm{Mg}^{2+} / \mathrm{Na}^{+}$ & $\mathrm{Ca}^{2+} / \mathrm{Na}^{+}$ & $\mathrm{SO}_{4}^{2-} / \mathrm{Na}^{+}$ & $\mathrm{Br}^{-} / \mathrm{Na}^{+}$ & $\mathrm{I} / \mathrm{Na}^{+}$ \\
\hline$t$ value & 2.939 & 3.585 & 2.920 & 4.113 & -3.449 & 4.668 & 3.186 \\
\hline$p$ value & 0.006 & 0.001 & 0.006 & $2.54 \times 10^{-4}$ & $1.60 \times 10^{-3}$ & $5.20 \times 10^{-5}$ & 0.003 \\
\hline Ratios & $\mathrm{Na}^{+} / \mathrm{Cl}^{-}$ & $\mathrm{K}^{+} / \mathrm{Cl}^{-}$ & $\mathrm{Mg}^{2+} / \mathrm{Cl}^{-}$ & $\mathrm{Ca}^{2+} / \mathrm{Cl}^{-}$ & $\mathrm{SO}_{4}^{2-} / \mathrm{Cl}^{-}$ & $\mathrm{Br}^{-} / \mathrm{Cl}^{-}$ & $\mathrm{I} / \mathrm{Cl}^{-}$ \\
\hline$t$ value & -3.925 & $-1.501^{\mathrm{d}}$ & $-1.470^{\mathrm{d}}$ & $-1.515^{\mathrm{d}}$ & -4.035 & $0.079^{\mathrm{d}}$ & $0.176^{\mathrm{d}}$ \\
\hline \multirow[t]{2}{*}{$p$ value } & 0.00045 & $0.143^{\mathrm{d}}$ & $0.151^{\mathrm{d}}$ & $0.139^{d}$ & $3.18 \times 10^{-4}$ & $0.937^{\mathrm{d}}$ & $0.861^{\mathrm{d}}$ \\
\hline & \multicolumn{7}{|c|}{ Frost flowers-snow ${ }^{b}$} \\
\hline Ratios & $\mathrm{Cl}^{-} / \mathrm{Na}^{+}$ & $\mathrm{K}^{+} / \mathrm{Na}^{+}$ & $\mathrm{Mg}^{2+} / \mathrm{Na}^{+}$ & $\mathrm{Ca}^{2+} / \mathrm{Na}^{+}$ & $\mathrm{SO}_{4}^{2-} / \mathrm{Na}^{+}$ & & \\
\hline$t$ value & $0.114^{\mathrm{d}}$ & -2.981 & 5.835 & -6.698 & $-1.083^{\mathrm{d}}$ & & \\
\hline$p$ value & $0.910^{\mathrm{d}}$ & 0.005 & $1.16 \times 10^{-6}$ & $8.20 \times 10^{-8}$ & $0.286^{\mathrm{d}}$ & & \\
\hline Ratios & $\mathrm{Na}^{+} / \mathrm{Cl}^{-}$ & $\mathrm{K}^{+} / \mathrm{Cl}^{-}$ & $\mathrm{Mg}^{2+} / \mathrm{Cl}^{-}$ & $\mathrm{Ca}^{2+} / \mathrm{Cl}^{-}$ & $\mathrm{SO}_{4}^{2-} / \mathrm{Cl}^{-}$ & & \\
\hline$t$ value & $-0.648^{d}$ & -3.248 & 5.492 & -5.844 & $-1.120^{\mathrm{d}}$ & & \\
\hline \multirow[t]{2}{*}{$p$ value } & $0.521^{\mathrm{d}}$ & 0.003 & $3.32 \times 10^{-6}$ & $1.122 \times 10^{-6}$ & $0.270^{\mathrm{d}}$ & & \\
\hline & \multicolumn{7}{|c|}{ Snow-brine ${ }^{c}$} \\
\hline Ratios & $\mathrm{Cl}^{-} / \mathrm{Na}^{+}$ & $\mathrm{K}^{+} / \mathrm{Na}^{+}$ & $\mathrm{Mg}^{2+} / \mathrm{Na}^{+}$ & $\mathrm{Ca}^{2+} / \mathrm{Na}^{+}$ & $\mathrm{SO}_{4}^{2-} / \mathrm{Na}^{+}$ & & \\
\hline$t$ value & $1.271^{\mathrm{d}}$ & 4.936 & -3.175 & 6.228 & $-1.730^{\mathrm{e}}$ & & \\
\hline$p$ value & $0.217^{\mathrm{d}}$ & $4.88 \times 10^{-5}$ & 0.004 & $1.95 \times 10^{-6}$ & $0.096^{\mathrm{e}}$ & & \\
\hline Ratios & $\mathrm{Na}^{+} / \mathrm{Cl}^{-}$ & $\mathrm{K}^{+} / \mathrm{Cl}^{-}$ & $\mathrm{Mg}^{2+} / \mathrm{Cl}^{-}$ & $\mathrm{Ca}^{2+} / \mathrm{Cl}^{-}$ & $\mathrm{SO}_{4}^{2-} / \mathrm{Cl}^{-}$ & & \\
\hline$t$ value & $-1.332^{\mathrm{d}}$ & $-0.621^{\mathrm{d}}$ & -3.328 & $-0.079^{\mathrm{d}}$ & $-1.962^{\mathrm{e}}$ & & \\
\hline$p$ value & $0.196^{\mathrm{d}}$ & $0.541^{\mathrm{d}}$ & 0.003 & $0.938^{\mathrm{d}}$ & $0.062^{\mathrm{e}}$ & & \\
\hline
\end{tabular}

${ }^{a}$ Thirty-two degrees of freedom. ${ }^{b}$ Thirty-six degrees of freedom. ${ }^{c}$ Twenty-four degrees of freedom. ${ }^{\mathrm{d}, \mathrm{e}}$ indicates "insignificant" and "slightly significant", respectively.

flowers (similar to the seawater ratio) at Barrow, Alaska, or at Hudson Bay, Canada. Furthermore, the slope of $\mathrm{Mg}^{2+}-\mathrm{Na}^{+}$ in surface snow on sea ice was lower than the seawater ratio, although $\mathrm{Mg}^{2+}-\mathrm{Na}^{+}$ratios from fresh snow samples with $\mathrm{Na}^{+}$concentrations lower than $0.1 \mathrm{mmol} \mathrm{L}^{-1}$ were similar to the seawater ratio.

\subsection{Aging of frost flowers and brine on sea ice}

Figure 5 presents variations of $\mathrm{CF}_{\mathrm{Na}}$ and molar ratio of $\mathrm{SO}_{4}^{2-} / \mathrm{Cl}^{-}$in frost flowers at site I. As described above, aged frost flowers, young frost flowers, and fresh frost flowers were collected respectively at sites I, II, IIIa, and IIIb. The values of $\mathrm{CF}_{\mathrm{Na}}$ of all samples exceeded 1.0, even on new ice at sites IIIa and IIIb, indicating that concentrated brine was excluded from sea ice to the sea-ice surface during sea-ice formation before the frost flower formation (Fig. 5a). Some samples with low $\mathrm{CF}_{\mathrm{Na}}$ at sites I and II could have been contaminated with minimal snowfall. The $\mathrm{CF}_{\mathrm{Na}}$ of frost flowers at sites IIIa and IIIb was lower than that at sites I and II, which suggests that sea-salt concentrations and sea-salt ratios of frost flowers varied depending on the age of frost flowers and sea ice.

To ascertain the changes in sea-salt components that occur along with the aging of frost flowers, we attempted to monitor the sea-salt components of frost flowers and brine at site I on 20-28 February 2014. Figure 6 depicts short-term variations of air temperatures measured by AWS ( $\left.T_{\mathrm{AWS}}\right)$, air temperature above frost flowers $\left(T_{\text {air }}\right.$, ca. $10 \mathrm{~cm}$ above the brine/sea-ice surface), temperatures at the base of frost flowers $\left(T_{\mathrm{FF}}\right)$, and molar ratios of sea salts $\left(\mathrm{SO}_{4}^{2-} / \mathrm{Na}^{+}\right.$, $\mathrm{SO}_{4}^{2-} / \mathrm{Cl}^{-}, \mathrm{Br}^{-} / \mathrm{Cl}^{-}, \mathrm{I} / \mathrm{Cl}^{-}, \mathrm{Mg}^{2+} / \mathrm{Cl}^{-}, \mathrm{K}^{+} / \mathrm{Cl}^{-}$, and $\mathrm{Ca}^{2+} / \mathrm{Cl}^{-}$) in frost flowers and brine. Unfortunately, we did not measure $T_{\text {air }}$ and $T_{\mathrm{FF}}$ on 20-22 February. $T_{\mathrm{AWS}}$ during 20-28 February was lower than the temperature for mirabilite formation (ca. $-9^{\circ} \mathrm{C}$ ). In addition, $T_{\mathrm{FF}}$ was -18.9 to $-21.3^{\circ} \mathrm{C}$ on $24-28$ February. Figure 6a shows that $T_{\mathrm{AWS}}$ and $T_{\text {air }}$ were lower than $-25^{\circ} \mathrm{C}$ beginning on 23 February. Sea-salt ratios in brine at site I were distributed similarly to seawater ratios. In contrast to the ratios in brine, molar ratios of $\mathrm{SO}_{4}^{2-} / \mathrm{Na}^{+}$in frost flowers de- 

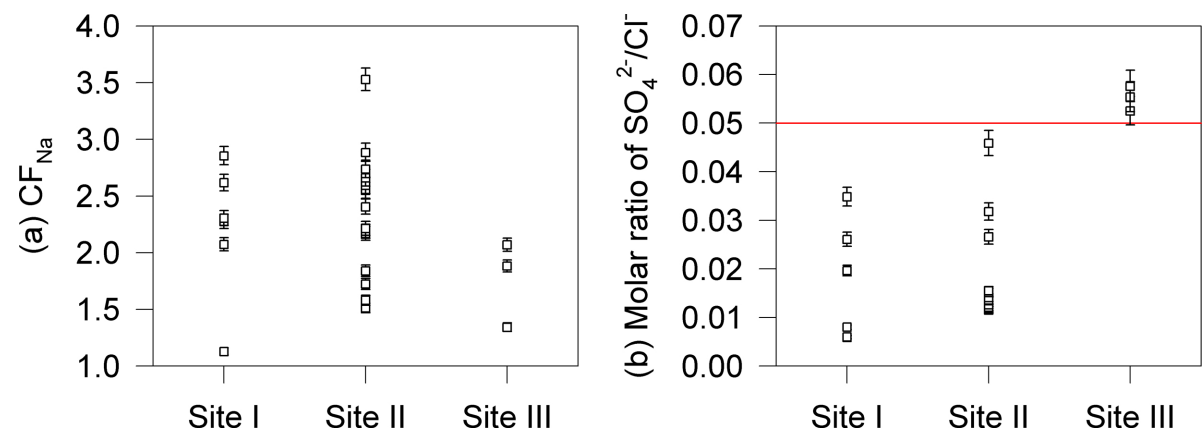

Figure 5. Variations of (a) concentration factor of $\mathrm{Na}^{+}\left(\mathrm{CF}_{\mathrm{Na}}\right)$ and (b) molar ratios of $\mathrm{SO}_{4}^{2-} / \mathrm{Na}^{+}$in frost flowers at each sampling site. The red line indicates the bulk seawater ratio. Error bars indicate standard deviation $(1 \sigma)$ of analytical errors.

creased considerably relative to seawater ratios. Although the molar ratios of $\mathrm{SO}_{4}^{2-} / \mathrm{Na}^{+}$in frost flowers did not change greatly on 26 February, other sea-salt ratios $\left(\mathrm{Mg}^{2+} / \mathrm{Cl}^{-}\right.$, $\mathrm{K}^{+} / \mathrm{Cl}^{-}$, and $\mathrm{Ca}^{2+} / \mathrm{Cl}^{-}$) increased simultaneously. In addition, $\mathrm{Na}^{+} / \mathrm{Cl}^{-}$ratios in frost flowers dropped slightly on 26 February. Molar ratios of $\mathrm{Br}^{-} / \mathrm{Cl}^{-}$and $\mathrm{I} / \mathrm{Cl}^{-}$in frost flowers were higher than the seawater ratio (values in literature) and brine (Fig. 6d, e). As described above, $\mathrm{Br}^{-}$and I were enriched in frost flowers at site I. Although ratios of $\mathrm{Mg}^{2+} / \mathrm{Cl}^{-}, \mathrm{K}^{+} / \mathrm{Cl}^{-}, \mathrm{Ca}^{2+} / \mathrm{Cl}^{-}$, and $\mathrm{Br}^{-} / \mathrm{Cl}^{-}$increased on 26-28 February, increases in the ratio of $\mathrm{I} / \mathrm{Cl}^{-}$were not clear.

Although the molar ratios of $\mathrm{Mg}^{2+} / \mathrm{Cl}^{-}, \mathrm{K}^{+} / \mathrm{Cl}^{-}$, and $\mathrm{Ca}^{2+} / \mathrm{Cl}^{-}$cannot be changed by mirabilite precipitation, these ratios increased on 26 February when $T_{\mathrm{FF}}$ dropped approximately to the temperature for hydrohalite precipitation. Because of analytical errors 2-4 times smaller than the differences of their molar ratios, it is expected that hydrohalite precipitation results in changes in the molar ratios. To ascertain the contribution of hydrohalite precipitation, we attempted to estimate the sea-salt ratios using the following assumptions.

1. Only mirabilite precipitated over 20-24 February.

2. There was no hydrohalite precipitation over 20 24 February.

3. Hydrohalite precipitation began on 26 February.

4. Sea salts other than mirabilite and hydrohalite were not fractionated on 20-28 February.

Assuming mirabilite precipitation on 20-24 February, seasalt ratios in the residual brine are given as shown in Eq. (3). Under this assumption, $\mathrm{Mg}^{2+}$ was not precipitated. Therefore, $\mathrm{Mg}^{2+} / \mathrm{Cl}^{-}$ratios did not change in mirabilite precipitation, as follows.

$\left(\frac{\left[\mathrm{Mg}^{2+}\right]}{\left[\mathrm{Cl}^{-}\right]}\right)_{\text {Seawater }}=\left(\frac{\left[\mathrm{Mg}^{2+}\right]}{\left[\mathrm{Cl}^{-}\right]}\right)_{\mathrm{SO}_{4}-\text { depleted }}$

Here, $\quad\left(\left[\mathrm{Mg}^{2+}\right] /\left[\mathrm{Cl}^{-}\right]\right)_{\text {seawater }} \quad$ and $\left(\left[\mathrm{Mg}^{2+}\right] /\left[\mathrm{Cl}^{-}\right]\right) \mathrm{SO}_{4}-$ depleted respectively denote the molar ratios of seawater collected at Siorapaluk and the residual brine after mirabilite precipitation. When hydrohalite precipitation occurred, the $\mathrm{Cl}^{-}$concentrations in the residual brine $\left(\left[\mathrm{Cl}^{-}\right]_{\text {hydrohalite-depleted }}\right)$ decreased gradually with hydrohalite precipitation as follows.

$\left[\mathrm{Cl}^{-}\right]_{\text {hydrohalite-depleted }}$

$=\left[\mathrm{Cl}^{-}\right]_{\text {seawater }}-\left[\mathrm{Cl}^{-}\right]_{\text {hydrohalite }}$

Here, $\left[\mathrm{Cl}^{-}\right]_{\text {hydrohalite }}$ and $\left[\mathrm{Cl}^{-}\right]_{\text {seawater }}$ respectively stand for the amount of $\mathrm{Cl}^{-}$in hydrohalite and the $\mathrm{Cl}^{-}$concentration in seawater or brine. Therefore, $\mathrm{Mg}^{2+} / \mathrm{Cl}^{-} \mathrm{ra}-$ tios in the residual brine after hydrohalite precipitation $\left(\left(\left[\mathrm{Mg}^{2+}\right] /\left[\mathrm{Cl}^{-}\right]\right)_{\text {hydrohalite-depleted }}\right)$ are given as shown below.

$$
\left(\frac{\left[\mathrm{Mg}^{2+}\right]}{\left[\mathrm{Cl}^{-}\right]}\right)_{\text {hydrohalite-depleted }}
$$

$=\frac{\left[\mathrm{Mg}^{2+}\right]_{\text {seawater }}}{\left[\mathrm{Cl}^{-}\right]_{\text {hydrohalite-depleted }}}$

$\left[\mathrm{Mg}^{2+}\right]_{\text {seawater }}$ represents the $\mathrm{Mg}^{2+}$ concentration in seawater or brine. In fact, $\left[\mathrm{Cl}^{-}\right]_{\text {hydrohalite }}$ in Eq. (6) can be estimated by substitution of the ambient $\mathrm{Mg}^{2+} / \mathrm{Cl}^{-}$ratio in frost flowers on 28 February $\left(\mathrm{Mg}^{2+} / \mathrm{Cl}^{-} \approx 0.103\right)$ with $\left.\left[\mathrm{Mg}^{2+}\right] /\left[\mathrm{Cl}^{-}\right]\right)_{\text {hydrohalite-depleted }}$ Then, the other sea-salt ratios after hydrohalite precipitation $\left(\left([\mathrm{X}] /\left[\mathrm{Cl}^{-}\right]\right)_{\text {hydrohalite-depleted }}\right)$ can be given as the equation below.

$\left(\frac{[\mathrm{X}]}{\left[\mathrm{Cl}^{-}\right]}\right)_{\text {hydrohalite-depleted }}=\frac{[\mathrm{X}]_{\text {seawater }}}{\left[\mathrm{Cl}^{-}\right]_{\text {hydrohalite-depleted }}}$

The amount of $\mathrm{Na}^{+}$in hydrohalite $\left(\left[\mathrm{Na}^{+}\right]_{\text {hydrohalite }}\right)$ was the same as that in $\left[\mathrm{Cl}^{-}\right]_{\text {hydrohalite. Therefore, the other }}$ sea-salt ratios relative to $\mathrm{Na}^{+}$after hydrohalite precipitation $\left(\left([\mathrm{X}] /\left[\mathrm{Na}^{+}\right]\right)_{\text {hydrohalite-depleted }}\right)$ can be estimated using the same procedure. As presented in Fig. 6, the ratios of $\mathrm{Na}^{+} / \mathrm{Cl}^{-}$in frost flowers were close to the estimated ratios in hydrohalite precipitation. 


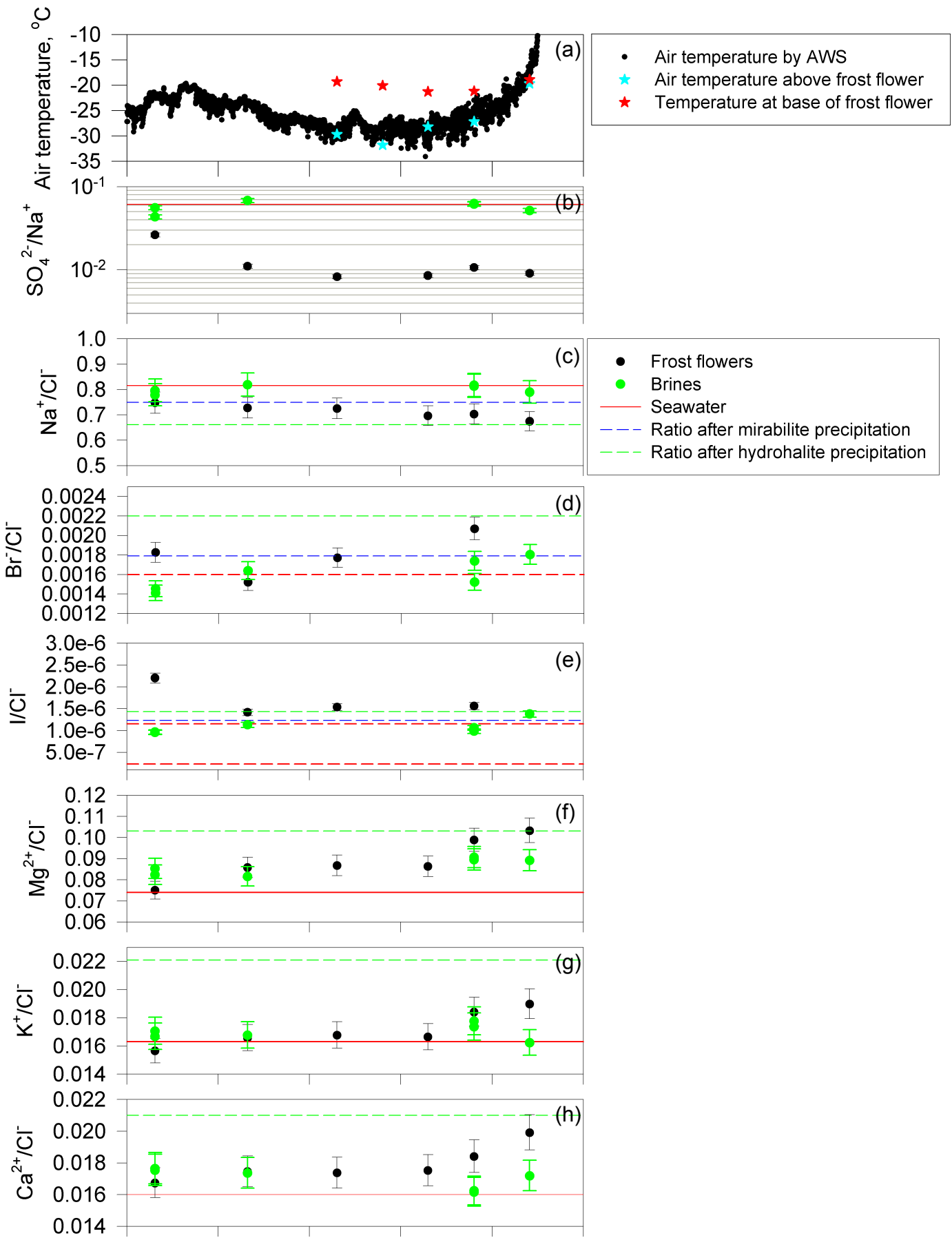

Feb. 20 Feb. 22 Feb. 24 Feb. 26 Feb. 28 Mar. 2

2014

Figure 6. Short-term features of (a) air temperature measured by AWS ( $\left.T_{\mathrm{AWS}}\right)$, air temperature above frost flowers $\left(T_{\text {air }}, \mathrm{ca} .10 \mathrm{~cm}\right.$ above the sea-ice surface), temperature of base of frost flowers $\left(T_{\mathrm{FF}}\right)$, and $(\mathbf{b}-\mathbf{h})$ molar ratios of sea salts in frost flowers and brine at site I. $T_{\text {air }}$ and $T_{\mathrm{FF}}$ were not measured on 20-22 February. Error bars indicate standard deviation $(1 \sigma)$ of analytical errors. Blue and green dashed lines show the molar ratios after precipitation of mirabilite and hydrohalite, respectively. 


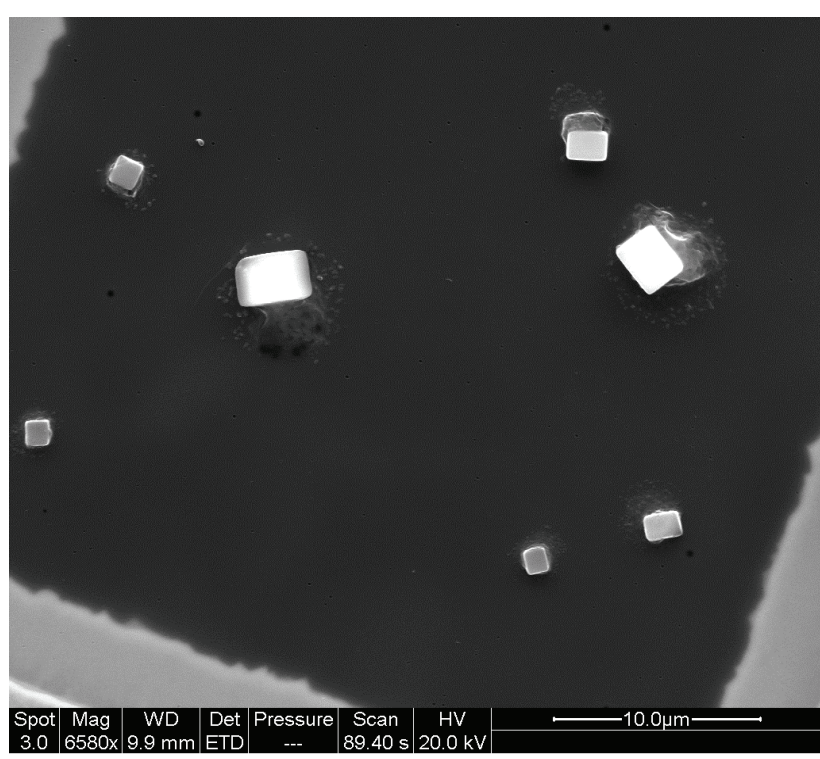

Figure 7. SEM image of aerosol particles collected on 1 March 2014 above the sea-ice area with frost flowers.

\subsection{Morphology of sea-salt particles}

Figure 7 depicts SEM images of aerosol particles collected above the sea-ice area with frost flowers. Most coarse aerosol particles collected on 1 March 2014 had structures with cuboid-crystal-like materials (bright color in SEM image) and non-crystal materials around the cuboid-crystal-like materials (gray-dark gray color in SEM image). Furthermore, most aerosol particles had stains around the particles. The presence of stains is direct evidence that the aerosol particles had a liquid surface in the atmosphere. We detected $\mathrm{Na}, \mathrm{Cl}$, and $\mathrm{Mg}$ in aerosol particles of this type. Therefore, the particles might be identified as sea-salt particles. Strong peaks of $\mathrm{Na}$ and $\mathrm{Cl}$ were identified from cuboid-crystal-like materials, whereas strong peaks of minor sea salts such as $\mathrm{Mg}, \mathrm{K}$, and $\mathrm{S}$ were also obtained from non-crystal materials. Depending on the amount (mass) of sea salts and water in a sea-salt particle, salts with lower solubility can exist in a state with a solid core. In SEM observations, however, aerosol particles were exposed to high-vacuum conditions. They dried up. The localization of each sea salt in a particle might proceed in a high-vacuum chamber. Therefore, it is worth noting that the salt distribution in an SEM image differed from the state in the ambient atmosphere.

\subsection{Elemental compositions of sea salts and relating salts in each aerosol particle}

Figure 8 depicts EDX spectra of sea-salt and sea-salt-related particles in aerosol particles collected over the sea ice. In accordance with procedures of aerosol classification presented by Hara et al. $(2013,2014)$ and atomic ratios of the respective particles, the mixing states of sea-salt particles and related salt particles were classified into the following types: (1) seasalt particles having atomic ratios similar to those of seawater (Fig. 8a); (2) Mg-rich sea-salt particles (Fig. 8b); (3) Krich sea-salt particles (Fig. 8c); (4) modified sea-salt particles with a slight $\mathrm{Cl}$ loss (Fig. 8d); (5) wholly modified sea-salt particles (Fig. 8e); (6) sea-salt particles internally mixed with mineral elements such as $\mathrm{Al}$ and $\mathrm{Si}$ (Fig. 8f); (7) $\mathrm{Na}_{2} \mathrm{SO}_{4}$ particles without $\mathrm{Mg}$ (Figs. $8 \mathrm{~g}$, and $\mathrm{S} 6$ ); (8) $\mathrm{MgCl}_{2}$ particles (Fig. 8h); (9) $\mathrm{MgSO}_{4}$ particles (Fig. 8i); and (10) $\mathrm{KCl}$ particles (Fig. 8j). Figure $\mathrm{S} 7$ shows that $\mathrm{Mg}$ in sea-salt particles might be present as $\mathrm{MgCl}_{2}$. In fact, $\mathrm{Mg}$ and $\mathrm{S}$ were detected from aerosol particles in Fig. 8i. Atomic ratios of $\mathrm{Mg}$ and $\mathrm{S}$ of the aerosol particles containing only $\mathrm{Mg}$ and $\mathrm{S}$ were approximately compatible with $\mathrm{MgSO}_{4}$. In fact, $\mathrm{Mg}$-rich seasalt particles, K-rich sea-salt particles, $\mathrm{Mg}$-salt particles, and $\mathrm{K}$-salt particles were identified also in the boundary layer over Syowa Station, Antarctica, during winter-spring (Hara et al., 2013) and near the surface on the Antarctic Plateau during summer (Hara et al., 2014). Additionally, aerosol particles with atomic ratios similar to $\mathrm{CaCO}_{3}$ were observed in the same aerosol samples (shown in Supplement, Fig. S8). In this study, these particles were observed only in aerosol samples collected near new sea ice. In addition, aerosol particles containing sulfates, minerals, soot, and anthropogenic metals were observed in this study.

\subsection{Abundance of sea-salt and related salt particles}

For quantitative discussion, the relative abundance was estimated from the results of EDX analyses (Fig. 9). In this study, sea-salt and modified sea-salt particles were major components of the coarse mode. High abundance of sea-salt particles corresponded to strong winds, high aerosol number concentrations, and appearance of low clouds (fog) above open sea off Siorapaluk. Although a few samples showed low relative abundance of sea-salt particles and modified sea-salt particles, this result corresponded to high relative abundance of minerals, including those containing sulfates. However, it is worth noting that the low number concentrations in coarse mode in the atmosphere engender low number density on the sample substrates and engender high uncertainty. For number concentrations of less than $10 \mathrm{~L}^{-1}$ in $D_{\mathrm{p}}>2.0 \mu \mathrm{m}$, the number of the analyzed particles in coarse mode was 3 to 16 particles.

Aerosol particles containing sulfates were dominant in fine mode, although sulfate particles were observed rarely in coarse mode. The relative abundance of NSS sulfate particles in fine mode was roughly equivalent to that of the Arctic boundary layer around Svalbard (Hara et al., 2003). The relative abundance of sulfate particles in fine mode was higher under conditions with low wind speeds and low aerosol number concentrations. Sea-salt particles and modified sea-salt particles in fine mode showed relative abundance greater than $40 \%$ under conditions with strong winds or high aerosol number concentrations in coarse mode. 

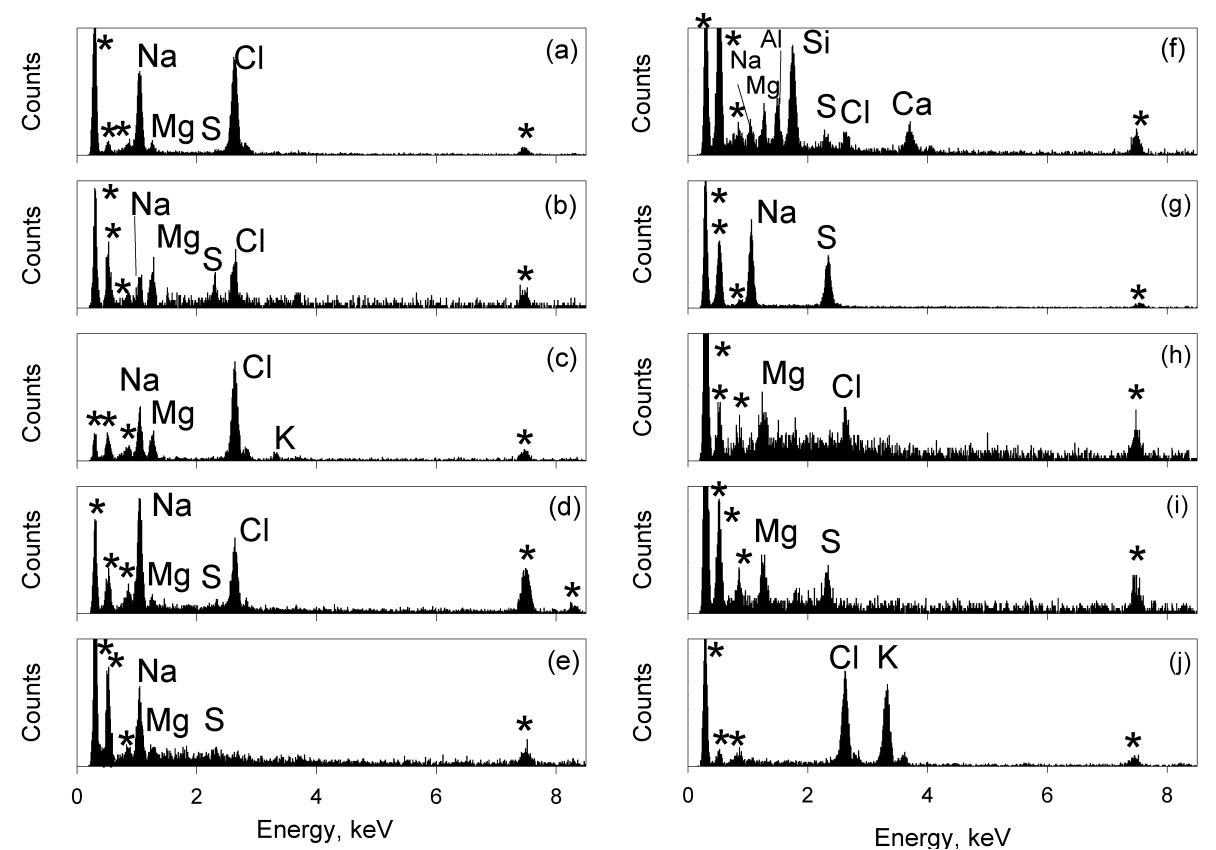

Figure 8. EDX spectra of sea-salt and sea-salt-related particles collected over the sea-ice area. Aerosol particles were collected (a) in coarse mode on 23 February 2014, (b) in fine mode on 20 February 2014, (c) in coarse mode on 21 February 2014, (d) in fine mode on 15 January February 2014, (e) in fine mode on 26 February 2014, (f) in coarse mode on 23 February 2014, (g) in coarse mode on 3 March 2014 , (h) in fine mode on 19 December 2013, (i) in fine mode on 15 January 2014, and (j) in coarse mode on 19 January 2014. Asterisks denote background peaks derived from the sample substrate.

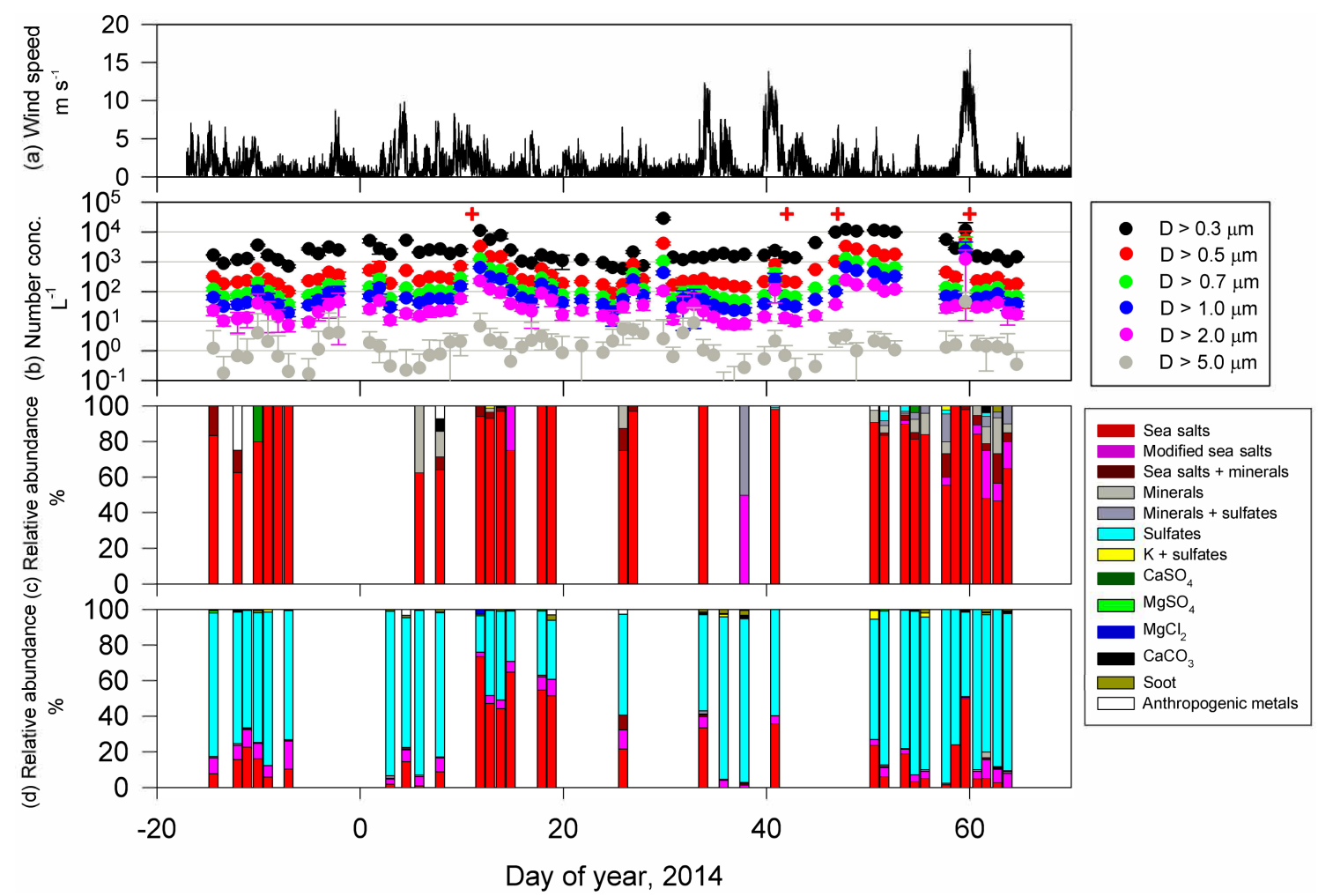

Figure 9. Variations of (a) wind speed, (b) aerosol number concentrations, relative abundance of each aerosol type in (c) coarse mode and (d) fine mode. Red plus (+) marks indicate the date when the low clouds (fogs) were identified off Siorapaluk. 
(a) 2014-0303

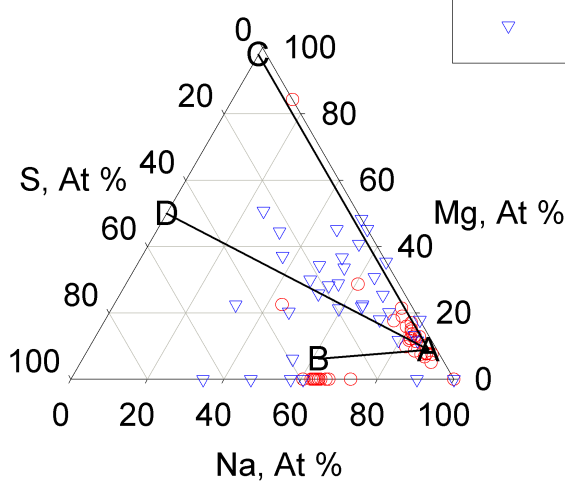

(c) 2014-0221

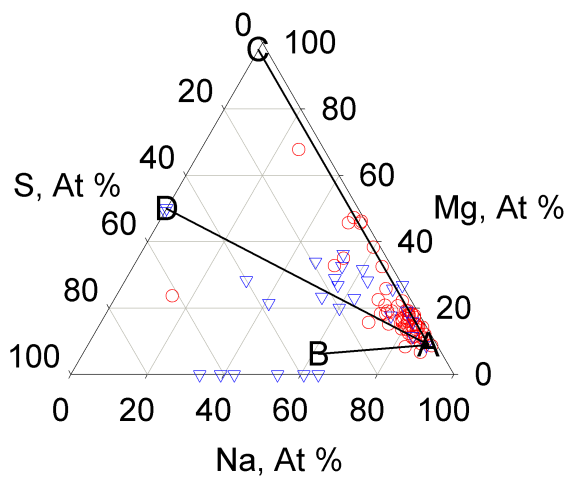

(b) 2014-0114

Fine

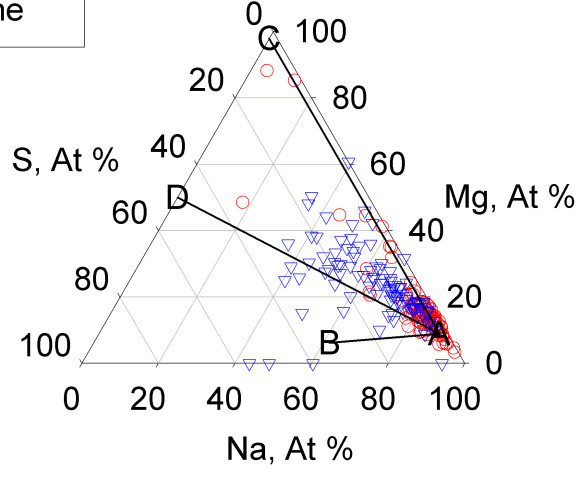

(d) 2014-0301

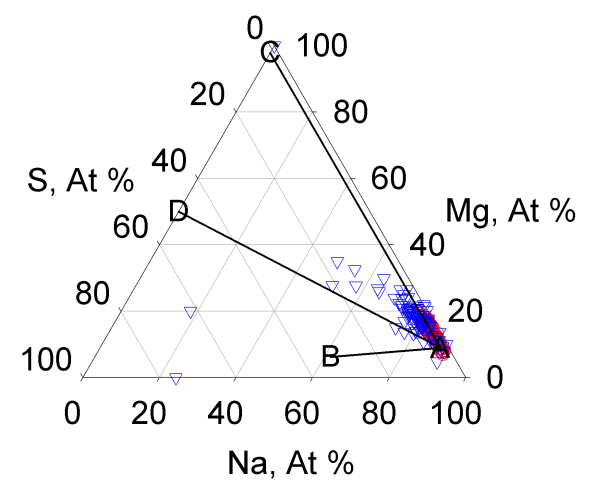

Figure 10. Ternary plots of $\mathrm{Na}-\mathrm{Mg}-\mathrm{S}$ of sea-salt particles and the modified sea-salt particles collected over the sea-ice area: (a) 3 March 2014, (b) 14 January 2014, (c) 21 February 2014, and (d) 3 January 2014. Letters A, B, C, and D within each panel denote, respectively, the ratios of seawater and those fully modified with $\mathrm{SO}_{4}^{2-}, \mathrm{MgCl}_{2}$, and $\mathrm{MgSO}_{4}$. Red open circles and blue triangles respectively present ratios of particles in coarse and fine modes. The notation "At \%" stands for atomic ratio (in percent).

\subsection{Sea-salt fractionation of aerosol particles in coarse and fine modes}

Figure 10 presents ternary plots of sea salts $(\mathrm{Na}, \mathrm{Mg}$, and $\mathrm{S}$ ) and $\mathrm{Mg}$-rich sulfates in coarse and fine modes. Internal mixtures of sea salts and minerals were excluded from the ternary plots. The sum of the atomic ratios of $\mathrm{Na}, \mathrm{S}$, and $\mathrm{Mg}$ in each sea-salt particle was not $100 \%$ in the most cases. Therefore, we converted the sum of the atomic ratios to $100 \%$ for ternary plots. Labels A, B, C, and D respectively denote the bulk seawater ratio, sea-salt particles (close to $\mathrm{MgCl}_{2}$ ) in which chloride was completely displaced by sulfate, sea-salt particles in which $\mathrm{Na}$ was completely replaced by $\mathrm{Mg}$, and sea-salt particles (close to $\mathrm{MgSO}_{4}$ ) in which chloride and $\mathrm{Na}$ were completely displaced by sulfate and $\mathrm{Mg}$, respectively. When the sea-salt particles are modified by sulfates and are not fractionated, they are distributed around the stoichiometric line of A-B. Magnesium in sea-salt particles can be enriched gradually with sea-salt fractionation by precipitation of mirabilite $\left(\mathrm{Na}_{2} \mathrm{SO}_{4} \cdot 10 \mathrm{H}_{2} \mathrm{O}\right)$ and hydrohalite $\left(\mathrm{NaCl} \cdot 2 \mathrm{H}_{2} \mathrm{O}\right.$; Hara et al., 2012). When sea-salt fractionation (replacement between $\mathrm{Na}$ and $\mathrm{Mg}$ ) occurs without sea-salt modification by sulfate, sea-salt particles are distributed around the stoichiometric line of A-C. When sea-salt fractionation and sea-salt modification by sulfate occur stoichiometrically and simultaneously, sea-salt particles are distributed around the stoichiometric line of $\mathrm{A}-\mathrm{D}$. The ratios of $\mathrm{Na}-\mathrm{Mg}-\mathrm{S}$ of frost flowers and brine were distributed around the bulk seawater ratio (point $\mathrm{A}$ ), although limited $\mathrm{Mg}$ enrichment was recognized in this study.

The $\mathrm{Mg}$ ratios in coarse aerosol particles collected near new sea ice (site IIIa) on 3 March were distributed mainly around the bulk seawater ratio and $\mathrm{NaSO}_{4}$ ratio (Fig. 10a). Magnesium was enriched slightly in some sea-salt particles, even in coarse modes. In contrast to the sea-salt particles, $\mathrm{Mg}$-free particles were distributed around the $\mathrm{Na}_{2} \mathrm{SO}_{4}$ ratio, as depicted in Fig. 8g. As described above, these particles distributed around the $\mathrm{Na}_{2} \mathrm{SO}_{4}$ ratio (point $\mathrm{B}$ ) might be 
mirabilite particles. In fine mode, most of the sea-salt particles were distributed between the stoichiometric lines of the seawater ratio- $\mathrm{MgSO}_{4}$ and seawater ratio- $\mathrm{MgCl}_{2}$. Unlike with the $\mathrm{Mg}$ ratio in coarse mode, $\mathrm{Mg}$ enrichment was remarkably observed in fine sea-salt particles.

Although most of the sea-salt particles in coarse mode were distributed around the bulk seawater ratio on 14 January and 21 February 2014 (Fig. 10b, c), some coarse seasalt particles had strong $\mathrm{Mg}$ enrichment and were distributed around the stoichiometric line of seawater ratio- $\mathrm{MgCl}_{2}$. A few particles showed atomic ratios that were roughly equal to that of $\mathrm{MgCl}_{2}$. Similarly to coarse sea-salt particles, $\mathrm{Mg}$ enrichment was also identified in fine mode on 14 January and 21 February 2014. However, Mg-rich sea-salt particles lay approximately midway between stoichiometric lines of seawater ratio- $\mathrm{MgCl}_{2}$ and seawater ratio- $\mathrm{MgSO}_{4}$. Moreover, $\mathrm{MgSO}_{4}$ particles were identified occasionally in this study (e.g., 21 February 2014).

In contrast to sea-salt particles on 14 January, 21 February, and 3 March 2014, sea-salt particles in both modes were distributed mostly around the seawater ratio under storm conditions with blowing and drifting snow on 1 March 2014 (Fig. 10d), although some sea-salt particles in coarse and fine modes had limited $\mathrm{Mg}$ enrichment. Winds came not from young sea-ice area with frost flowers (sites I and II) but from old and very old sea-ice areas.

\subsection{Variations of the fractionated sea-salt particles during winter}

Figure 11 presents variations of $\mathrm{Mg} / \mathrm{Na}$ ratios in sea-salt particles and wind speed. Sea-salt particles internally mixed with mineral particles were excluded from Fig. 11 to avoid misunderstanding of the sea-salt chemistry. The ratios of $\mathrm{Mg} / \mathrm{Na}$ were higher than the bulk seawater ratio $(\mathrm{Mg} / \mathrm{Na}$ of approximately 0.09 in seawater at Siorapaluk, and 0.11 in reports of seawater of the literature, Lide, 2005; Millero et al., 2008) in coarse and fine sea-salt particles during measurements. Higher $\mathrm{Mg} / \mathrm{Na}$ ratios and their large variation in sea-salt particles were observed in both coarse and fine modes under calm wind conditions. In conditions with blowing snow or strong winds $\left(>5 \mathrm{~m} \mathrm{~s}^{-1}\right)$, the $\mathrm{Mg} / \mathrm{Na}$ ratios and their standard deviation tended to decrease in both modes (particularly in fine mode). For instance, median $\mathrm{Mg} / \mathrm{Na}$ ratios in strong winds were ca. 0.18 in both modes on DOY 40 (10 February), and ca. 0.16 in coarse mode and 0.22 in fine mode on DOY 59 (1 March). Furthermore, $\mathrm{Mg} / \mathrm{Na}$ ratios in coarse sea-salt particles increased gradually on DOY 52 57 (22-27 February), when the air temperature was below $-25^{\circ} \mathrm{C}$ and the wind speed was less than $4 \mathrm{~m} \mathrm{~s}^{-1}$. After the storm on DOY 59 (1 March), Mg / Na ratios of sea-salt particles were distributed around the seawater ratio, although the ratios varied. In contrast to coarse sea-salt particles, $\mathrm{Mg} / \mathrm{Na}$ ratios were higher in fine modes in this study. Similar tendencies were observed for aerosol particles over Syowa Station,

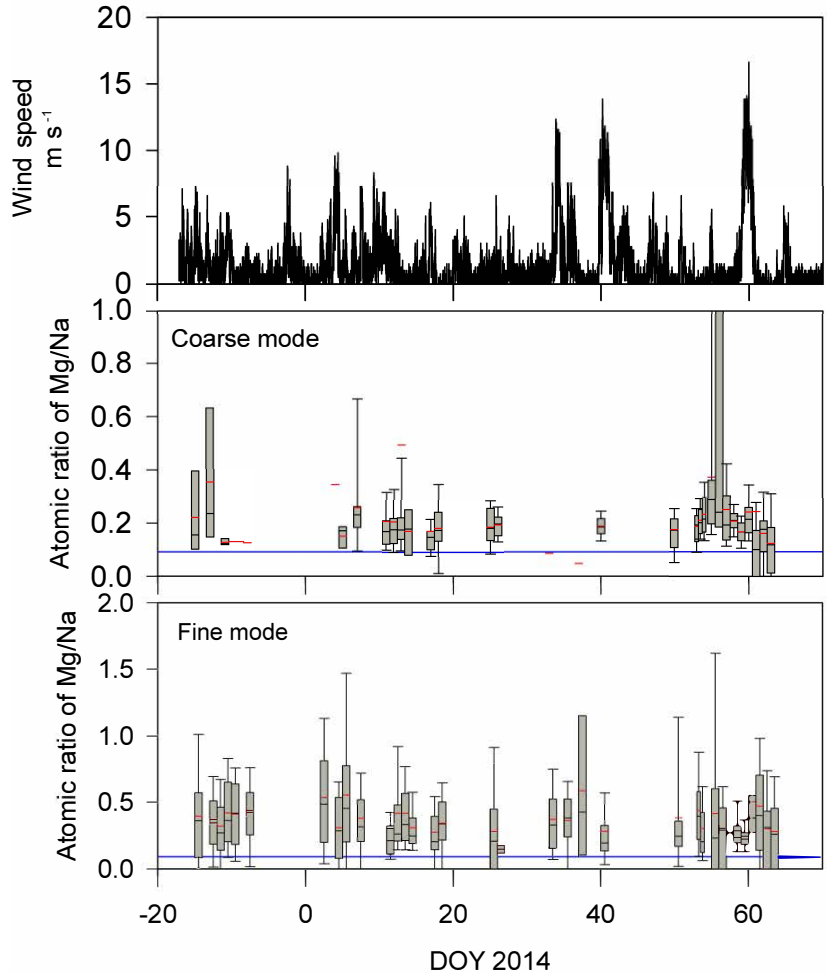

Figure 11. Variations of wind speed and atomic ratios of $\mathrm{Mg} / \mathrm{Na}$ in sea-salt particles and the modified sea-salt particles collected over the sea-ice area. The box plots show values of 90, 75, 50 (median), 25 , and $10 \%$ denoted, respectively, with the top bar, top box line, black middle box line, bottom box line, and bottom bar. The red lines show mean values of the seawater $\mathrm{Mg} / \mathrm{Na}$ ratio.

coastal Antarctica (Hara et al., 2013), and on the Antarctic continent (Hara et al., 2014). This size dependence of $\mathrm{Mg}$ enrichment of sea-salt particles is important to elucidate the processes of sea-salt particle release from sea ice and frost flowers.

\section{Discussion}

\subsection{Sea-salt fractionation on sea ice}

The molar ratios of $\mathrm{Cl}^{-} / \mathrm{Na}^{+}$in seawater collected at Siorapaluk were roughly equal to the ratios reported in the literature (Lide, 2005; Merrlet et al., 2008), although slight differences were identified in other ratios such as $\mathrm{K}^{+} / \mathrm{Na}^{+}$ and $\mathrm{Ca}^{2+} / \mathrm{Na}^{+}$. Considering the reproducibility of determination of sea-salt components in our analytical procedures, the differences (more than $10 \%$ ) between the seawater ratios collected at Siorapaluk and the literature values cannot be explained by analytical errors. According to Millero (2016), seawater concentrations and seawater ratios were varied in each sampling site. Indeed, differences in the seawater ratios (lower $\mathrm{K}^{+} / \mathrm{Na}^{+}$ratio) were observed at the Antarctic coast 
(Hara et al., 2012 and references therein). Therefore, the difference might result from differences of seawater ratios at the sampling location.

Coincidence of the ambient molar ratios in frost flowers and snow with the estimated molar ratios in mirabilite precipitation implies that the molar ratios relative to $\mathrm{Na}^{+}$in frost flowers and snow were affected strongly by mirabilite precipitation. Salt precipitation in sea-salt fractionation depends on temperature (Marion et al., 1999; Koop et al., 2000). Therefore, we attempted to compare the relationships of the respective sea salts to $\mathrm{Cl}^{-}$and $\mathrm{Mg}^{2+}$ (Figs. S1 and S2) for identification of sea-salt fractionation other than mirabilite precipitation. The molar ratios to $\mathrm{Cl}^{-}$were not changed by mirabilite precipitation without $\mathrm{Cl}^{-}$loss by heterogeneous reactions. Relationships among $\mathrm{Mg}^{2+}, \mathrm{K}^{+}, \mathrm{Ca}^{2+}$, and $\mathrm{Cl}^{-}$ in frost flowers well matched those in brine. Indeed, $t$ test results (Table 2) suggest that molar ratios of $\mathrm{Mg}^{2+}, \mathrm{K}^{+}$, and $\mathrm{Ca}^{2+}$ relative to $\mathrm{Cl}^{-}$in frost flowers were not significantly different from those in brine. Although frost flowers were more likely to be richer in $\mathrm{Br}^{-}$and $\mathrm{I}^{-}$than in $\mathrm{Cl}^{-}$and $\mathrm{Mg}^{2+}$ in most samples (Table 1, Figs. S3-S5), Student $t$ test results indicated no significant difference because of high ratios in a few brine samples. Considering that the first step of precipitation of $\mathrm{Na}$ salt is mirabilite precipitation approximately at $-9^{\circ} \mathrm{C}$, the coincidence of the relationships of among $\mathrm{Mg}^{2+}$, $\mathrm{K}^{+}, \mathrm{Ca}^{2+}$, and $\mathrm{Cl}^{-}$suggests that enrichment of $\mathrm{Mg}^{2+}, \mathrm{K}^{+}$, and $\mathrm{Ca}^{2+}$ in frost flowers was driven mainly by mirabilite precipitation. It is worth noting that $t$ tests were applied to all measurements of frost flowers and snow of different ages. Therefore, we must consider changes in molar ratios carefully if sea-salt fractionation other than mirabilite precipitation had proceeded with aging of frost flowers (details are discussed in the next section).

Considering the presence of $\mathrm{MgCl}_{2}$ and $\mathrm{MgSO}_{4}$ in aerosol particles, $\mathrm{Mg}$ salts might be present in frost flowers and the slush layer. According to earlier laboratory and model studies (e.g., Mairon et al., 1999), $\mathrm{MgCl}_{2} \cdot 6 \mathrm{H}_{2} \mathrm{O}$ and $\mathrm{KCl}$ (sylvite) can precipitate respectively at approximately -36 and $-34{ }^{\circ} \mathrm{C}$. During the measurements, the minimum air temperature $\left(-34.1^{\circ} \mathrm{C}\right)$ and temperature at the surface of the slush layer $\left(T_{\mathrm{FF}}\right)$ were higher than the temperature at which $\mathrm{MgCl}_{2} \cdot 6 \mathrm{H}_{2} \mathrm{O}$ precipitates. Therefore, $\mathrm{MgCl}_{2} \cdot 6 \mathrm{H}_{2} \mathrm{O}$ precipitation might not have occurred during the measurements. In other words, $\mathrm{Mg}^{2+}$ might be distributed in the residual brine on frost flowers and in the slush layer and snow.

\subsection{Aging of frost flowers and sea-salt fractionation}

Molar ratios of $\mathrm{SO}_{4}^{2-} / \mathrm{Cl}^{-}$in frost flowers at sites $\mathrm{I}$ and II (Fig. 5b) were considerably lower than the seawater ratio. This change in $\mathrm{SO}_{4}^{2-} / \mathrm{Cl}^{-}$ratios might be attributed to sea-salt fractionation by sulfate depletion (i.e., mirabilite precipitation). By contrast, $\mathrm{SO}_{4}^{2-} / \mathrm{Cl}^{-}$ratios at site III were roughly equivalent to the seawater ratio. Considering direct evidence indicating that mirabilite-like particles were iden- tified in aerosols only at sites IIIa and IIIb, we believe that mirabilite might be precipitated in the early sea-ice stage. Details of mirabilite-like particles are discussed in Sect. 4.3.

At site I, sea-salt ratios changed gradually with growth and aging of frost flowers, as shown in Fig. 6. As discussed in Sect. 4.1, lower $\mathrm{SO}_{4}^{2-} / \mathrm{Na}^{+}$ratios might result from the mirabilite precipitation. Moreover, the ratios of $\mathrm{Mg}^{2+} / \mathrm{Cl}^{-}, \mathrm{K}^{+} / \mathrm{Cl}^{-}$, and $\mathrm{Ca}^{2+} / \mathrm{Cl}^{-}$increased simultaneously and $\mathrm{Na}^{+} / \mathrm{Cl}^{-}$decreased slightly on 26-28 February when $T_{\mathrm{FF}}$ dropped approximately to the temperature for hydrohalite precipitation (ca. $-22^{\circ} \mathrm{C}$ ). This simultaneous change might not result from analytical errors because the differences were 2-3 times larger than analytical errors $(1 \sigma)$. The ambient molar ratios of $\mathrm{Na}^{+} / \mathrm{Cl}^{-}$in frost flowers were similar to the estimated ratios in hydrohalite precipitation, although the ratios were slightly lower than the estimated ratios. The cation $\mathrm{Ca}^{2+}$ can be fractionated by precipitation of ikaite $\left(-2.2^{\circ} \mathrm{C}\right.$, Dieckmann et al., 2008, 2010) and gypsum $\left(-15^{\circ} \mathrm{C}\right.$, Marion et al., 1999). Therefore, lower ratios of $\mathrm{Ca}^{2+} / \mathrm{Cl}^{-}$might result from precipitation of these salts. Presence of K-rich sea-salt particles and K-salt particles in sea-salt particles in the atmosphere implies that seasalt fractionation with $\mathrm{K}^{+}$occurred in our measurements, although sylvite can be precipitated at $-33^{\circ} \mathrm{C}$ (Marion et al., 1999). The coincidence implies that the molar ratios in frost flowers on 26-28 February were attributed to hydrohalite precipitation. In contrast to $T_{\mathrm{FF}}, T_{\text {air }}$ increased slightly on 26-27 February. Then it increased greatly on 28 February1 March. In spite of the slight increase of $T_{\mathrm{AWS}}$ and $T_{\mathrm{air}}, T_{\mathrm{FF}}$ tended to decrease slightly during 24-27 February. This decrease of $T_{\mathrm{FF}}$ might be attributed to reduction of heat conduction by sea-ice growth (larger thickness). Consequently, it is expected that the sea-ice thickness was a fundamentally important factor for sea-salt fractionation on sea ice, in addition to $T_{\text {air }}$.

It is worth noting that molar ratios in frost flowers cannot change if sea-salt fractionations such as mirabilite and hydrohalite precipitation occur on frost flowers after brine migration onto frost flowers. Regardless of whether mirabilite and hydrohalite were precipitated on frost flowers or not, the total amount (mass) of precipitated salts and sea salts in residual brine did not change without liberation by heterogeneous reactions. The cations $\mathrm{Mg}^{2+}, \mathrm{K}^{+}$, and $\mathrm{Ca}^{2+}$ cannot be released into the atmosphere by heterogeneous reactions. Results show that $T_{\mathrm{FF}}$ was lower than the temperature at which mirabilite and hydrohalite precipitates and higher than those for sylvite, $\mathrm{MgCl}_{2} \cdot 6 \mathrm{H}_{2} \mathrm{O}$, and $\mathrm{NaBr} \cdot 5 \mathrm{H}_{2} \mathrm{O}$ (e.g., Marion, 1999; Koop et al., 2000). Therefore, Mg might be enriched in the residual brine. Precipitation of mirabilite and hydrohalite might be driven near the surface of brine on the sea ice, as suggested by (1) a change in the molar ratios in frost flowers, (2) non-significant change in those in brine, and (3) $T_{\mathrm{FF}}$ close to ca. $-21^{\circ} \mathrm{C}$. Then, the residual brine might be migrated vertically onto frost flowers. The ratios of $\mathrm{Br}^{-} / \mathrm{Cl}^{-}$and $\mathrm{I} / \mathrm{Cl}^{-}$in frost flowers were mostly higher 
than those in brine, except for a few brine samples. It is expected that $\mathrm{Br}^{-}$and I were richer in frost flowers because of sea-salt fractionation. However, the concentrations of $\mathrm{Br}^{-}$ and $I$ in seawater sampled at Siorapaluk were not determined in this study.

\subsection{Fractionated sea-salt particles in the atmosphere}

From single-particle analysis of aerosols, several types of salt particles, likely related to sea-salt fractionation, were identified in aerosols: (1) $\mathrm{Mg}$-rich sea-salt particles, (2) $\mathrm{Na}_{2} \mathrm{SO}_{4}$ particles, (3) $\mathrm{Mg}$-salt particles $\left(\mathrm{MgCl}_{2}\right.$ and $\left.\mathrm{MgSO}_{4}\right)$, (4) $\mathrm{K}$ rich sea-salt particles, (5) $\mathrm{KCl}$ particles, and (6) $\mathrm{CaCO}_{3}$ particles. With sea-salt fractionation in frost flowers, brine, and surface snow on sea ice, $\mathrm{Mg}^{2+}, \mathrm{K}^{+}$and $\mathrm{Ca}^{2+}$ were enriched in frost flowers and surface snow (excluding $\mathrm{Mg}^{2+}$ in surface snow). Therefore, Mg-rich sea-salt particles (Fig. 8b), K-rich sea-salt particles (Fig. 8c), Mg-salt particles (Figs. 8h-i), and $\mathrm{K}$-salt particles (Fig. 8j) might originate from the sea-ice area and might be associated with sea-salt fractionation. As presented in Fig. 8g, Mg was not detected in aerosol particles containing $\mathrm{Na}$ and $\mathrm{S}$. Magnesium ratios in coarse sea-salt particles usually exceed the detection limit of single particle analysis by EDX. Therefore, the aerosol particles might have an extremely low $\mathrm{Mg}$ ratio. The atomic ratios of $\mathrm{Na}$ and $\mathrm{S}$ of the $\mathrm{Mg}$-poor particles imply strongly that the particles were in the form of $\mathrm{Na}_{2} \mathrm{SO}_{4}$. If the sea-salt particles were modified with $\mathrm{SO}_{4}^{2-}$ by heterogeneous reactions (Supplement, Figs. S9-S10), then the modified sea-salt particles contained sea-salt $\mathrm{Mg}$. Consequently, the presence of $\mathrm{Na}_{2} \mathrm{SO}_{4}$ particles cannot be explained by their release from the sea surface and then sea-salt modification. Particles of $\mathrm{Na}_{2} \mathrm{SO}_{4}$ were observed only at new sea ice, sites IIIa and IIIb, where $\mathrm{CaCO}_{3}$-like particles were also identified. In the early stage of sea-ice formation, ikaite $\left(\mathrm{CaCO}_{3} \cdot 6 \mathrm{H}_{2} \mathrm{O}\right)$ and mirabilite $\left(\mathrm{Na}_{2} \mathrm{SO}_{4} \cdot 10 \mathrm{H}_{2} \mathrm{O}\right)$ can be precipitated respectively at -2 and $-8.8^{\circ} \mathrm{C}$ on/in sea ice (Dieckmann et al., 2008, 2010; Marion et al., 1999). Therefore, mirabilite-like and ikaite-like particles might be released into the atmosphere in the new sea-ice area.

Next, we specifically examined $\mathrm{Mg} / \mathrm{Na}$ ratios in sea-salt particles to elucidate the sea-salt cycles in seasonal seaice areas. Magnesium-rich sea-salts and Mg salts cannot be evaporated or vaporized under ambient conditions: these particles must be released through physical processes. Sea-salt fractionation can occur if sea-salt particles are fractured in the atmosphere. However, direct evidence of the fracture of sea-salt particles in the atmosphere has not been obtained (Lewis and Schwartz, 2004). The following evidence is important to elucidate the origins of $\mathrm{Mg}$-rich sea-salt particles and Mg-rich salt particles in the atmosphere: (1) the presence of highly $\mathrm{Mg}$-rich particles (Mg-rich sea-salts, $\mathrm{MgCl}_{2}$, and $\left.\mathrm{MgSO}_{4}\right)$, (2) $T_{\mathrm{FF}}$ lower than the temperature at precipitation of mirabilite and hydrohalite, (3) higher $\mathrm{Mg} / \mathrm{Na}$ ratio in fine mode, (4) small variation of the $\mathrm{Mg} / \mathrm{Na}$ ratio in strong winds and blowing snow, (5) high $\mathrm{Mg}^{2+} / \mathrm{Na}^{+}$ratios in frost flowers, and (6) $\mathrm{Mg}$ depletion in the aged surface snow on sea ice.

The $\mathrm{Mg} / \mathrm{Na}$ ratios in sea-salt particles differed greatly depending on the sampling site and meteorological conditions (e.g., winds and temperature) as presented in Fig. 11. It is worth noting that sea-salt particles at sites IIIa and IIIb were distributed around seawater ratios from DOY 60 (2 March). Therefore, most of the sea-salt particles, except mirabilite-like and ikaite-like particles at sites IIIa and IIIb, might have been released from the sea surface. Moreover, the presence of ikaite-like and mirabilite-like particles in the atmosphere implies that these particles were released into the atmosphere from the early stage of sea ice after precipitation of ikaite and mirabilite on sea ice and frost flowers. In contrast to $\mathrm{Mg} / \mathrm{Na}$ ratios in sea-salt particles at sites IIIa and $\mathrm{IIIb}$, higher $\mathrm{Mg} / \mathrm{Na}$ ratios than seawater ratios were identified at sites I and II. Higher $\mathrm{Mg} / \mathrm{Na}$ ratios in sea-salt particles suggest strongly that $\mathrm{Mg}$-rich sea-salt particles in the atmosphere were supplied from the sea-ice area with sea-salt fractionation. As shown in Fig. $4, \mathrm{Mg}^{2+} / \mathrm{Na}^{+}$ratios in frost flowers at site I increased gradually during 20 February to 1 March under colder conditions. The correlation between high $\mathrm{Mg} / \mathrm{Na}$ ratios in coarse mode and the coldest conditions implies strongly that $\mathrm{Mg} / \mathrm{Na}$ ratios in coarse sea-salt particles responded rapidly to sea-salt fractionation on sea ice and frost flowers.

Because of the aerosol number concentrations, relative abundance of sea-salt particles, and high $\mathrm{Mg} / \mathrm{Na}$ ratios relative to seawater ratios in strong winds, the fractionated sea-salt particles might have been dispersed from sea ice into the atmosphere by strong winds. Although high aerosol number concentrations were observed occasionally at Siorapaluk under calm winds, the features might result from transport of (1) sea-salt particles released elsewhere by strong winds and (2) anthropogenic aerosols (i.e., sulfates and Arctic haze). Because of the high abundance of sea-salt particles, most cases of higher aerosol number concentrations in calm winds were likely associated with the release from sea-ice area and transport of sea-salt particles. Similar phenomena (aerosol enhancement) were identified also at the Antarctic coast (Hara et al., 2010). As discussed above, Mg was likely richer in frost flowers and the residual brine on sea ice. Earlier investigations (Obbard et al., 2009; Roscoe et al., 2011) revealed, however, that no aerosol particles were released by the breakage of frost flowers under strong winds. Considering the direct evidence of $\mathrm{Mg}$ depletion in aged surface snow on sea ice, Mg-rich sea-salt particles and Mg-salt particles were likely released from surface snow mixed with the residual brine on sea ice. The variations of $\mathrm{Mg} / \mathrm{Na}$ ratios in sea-salt particles were smaller in both coarse and fine modes under storm conditions (DOY 40 and 59), although the $\mathrm{Mg}$ / Na ratios were higher than the seawater ratio. Winds passed from the old and very old sea-ice area to the sampling sites in the storm conditions. Consequently, Mg-rich 
(1) Initial stage: open water

(2) First stage: sea-ice formation

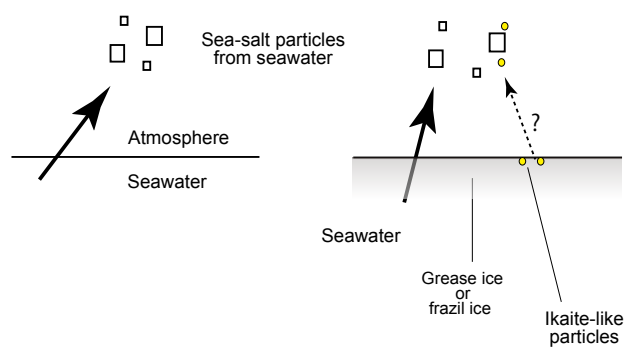

(5) Fourth stage: strong winds, snowfall

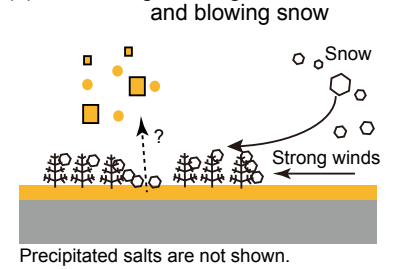

(6) Fifth stage: snow accumulation

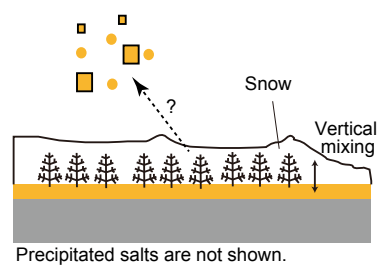

(3) Second stage: frost flower formation

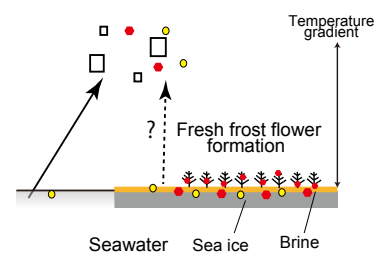

(4) Third stage: frost flower growth

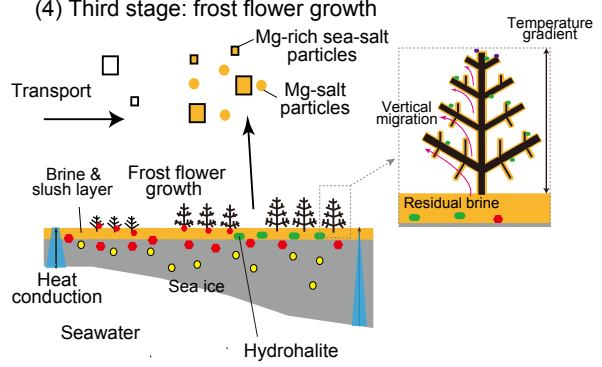

Figure 12. Schematics of sea-salt cycles in the sea-ice area. Dotted arrows indicate the speculated processes.

sea-salt particles in the storms might be released also from the snow layer on old and very old sea ice through erosion of snow by strong winds because the slush layer was absent on old and very old sea ice. By contrast, $\mathrm{Mg}$ / $\mathrm{Na}$ ratios varied largely under calm wind conditions. To explain the presence of highly Mg-rich sea-salt particles and Mg-rich salt particles, we inferred that these particles were released from the aged surface snow and the residual brine on slush layer and frost flowers through erosion of snow with the residual brine and splashing and shattering of the residual brine film. Higher Mg / Na ratios in fine sea-salt particles are eminently explainable if the processes proceeded on seasonal sea-ice areas. To elucidate these points, we must accumulate more information related to the salt distribution on and in frost flowers and sea ice at the nanometer-micrometer scale.

\subsection{Sea-salt cycles in seasonal sea-ice area}

From the evidence and results from this work and earlier works, we propose the following as hypotheses for the seasalt fractionation processes on sea ice and the release of seasalt particles into the atmosphere (Fig. 12).

Initial stage - open sea surface: Before sea-ice formation, sea-salt particles are released from the sea surface through bubble bursting and breaking waves (e.g., Lewis and Schwartz, 2004). Sea-salt ratios in the particles released by bubble bursting are similar to the seawater ratio (Keene et al., 2007).

First stage - seawater freezing: Seawater starts freezing at lower air temperatures. In this stage, sea ice was likely present in conditions of grease ice, frazil ice, and sludge (Comiso and Steffen, 2001; Brandt et al., 2005; Comiso,
2010). Considering that sea-salt particles with ratios similar to seawater were found to be present only at sites IIIa and IIIb, these particles must be released from the sea surface in the initial stage and first stage. Depending on the temperature at the sea-ice surface, ikaite can start precipitation at temperatures lower than $-2{ }^{\circ} \mathrm{C}$ (Dieckmann et al., 2008, 2010).

Second stage - sea-ice formation and sea-salt fractionation: Then, the sea-surface was covered with thin sea ice (i.e., nilas) at sites IIIa and IIIb. The presence of sea ice prevents the release of sea-salt particles from the sea surface into the atmosphere. A strong vertical gradient of air temperature near the sea-ice surface might cause frost flower formation on sea ice (e.g., Perovich and Richter-Menge, 1994; Martin et al., 1995, 1996; Style and Worster, 2009; Roscoe et al., 2011). Some brine can be migrated vertically on frost flowers. Cooling of surface of the frost flowers and brine on sea ice can engender precipitation of ikaite and mirabilite. The presence of ikaite-like particles and mirabilite-like particles in the atmosphere suggests that these particles are released into the atmosphere through physical processes. Mirabilite-like and ikaite-like particles were identified in aerosols collected only at sites IIIa and IIIb. Therefore, these particles might be released from fresh sea-ice areas. However, specific release processes remain unclear.

Third stage - frost flower growth and sea-salt fractionation: With sea-ice growth, the temperature on sea ice $\left(T_{\mathrm{FF}}\right)$ might decrease gradually by reduction of heat conduction from seawater to the sea-ice surface. Lower temperatures on and in the slush layer can induce 
sea-salt fractionation by precipitation of mirabilite and hydrohalite. Precipitation of mirabilite and hydrohalite can engender sea-salt enrichment (e.g., $\mathrm{Mg}^{2+}, \mathrm{K}^{+}$, and $\mathrm{Ca}^{2+}$ ) in frost flowers and the residual brine. The residual brine having $\mathrm{Mg}$ enrichment is migrated vertically on frost flowers.

Fourth stage - strong winds and snowfall on frost flowers: Under conditions with strong winds, snowfall, and blowing snow, snow particles were attached on frost flowers and slush layers. As suggested by laboratory experiments (Roscoe et al., 2010), no aerosol particles are released from frost flowers. However, $\mathrm{Mg}$-rich sea-salt particles and $\mathrm{Mg}$ salts might be released from the slush layer and surface snow on sea ice.

Fifth stage - frost flower and slush layer covered with snow: When snowfall and blowing snow are sufficient to cover frost flowers and the slush layer on new-young sea ice, frost flowers and slush layer are buried completely in snow after the storm. After snow deposition onto newyoung sea ice, the residual brine with $\mathrm{Mg}^{2+}$ enrichment might be migrated vertically and gradually into the snow layer. As a result, the snow layer on new-young sea ice was wet, as observed in this study. Sea salts in the migrated brine, frost flowers and snow can be redistributed through snow metamorphosis, although distributions of sea salts might be heterogeneous in the snow layer. Magnesium-rich sea-salt particles and $\mathrm{Mg}$-salt particles might be released from the surface snow on sea ice because of limited loss of $\mathrm{Mg}^{2+}$ in the aged surface snow on sea ice as shown in Figs. S1 and S4. Therefore, we speculate that splash and erosion of the residual brine on snow and frost flowers by winds are plausible release processes of Mg-rich sea-salt particles and $\mathrm{Mg}$-salt particles.

Sixth stage - snow erosion by strong winds: With sea-ice growth, snow and slush layers can be frozen gradually. Then, strong winds (i.e., storm condition) engender erosion of aged surface snow on sea ice and release of $\mathrm{Mg}$ rich sea-salt particles into the atmosphere. A dry and hard surface of sea ice appears after snow layers are removed from old and very old sea ice. Because of wet conditions in the snow and slush layer, a large amount of surface snow remained on the young sea ice.

We observed frost flowers and aerosols on sea ice in a fjord near Siorapaluk, Greenland. Therefore, we were able to compare respective sea-ice stages easily. If sea-ice areas having frost flowers are present in the locations affected strongly by winds, waves, tides, and ocean currents (e.g., Arctic Ocean and Antarctic coast), then sea ice can flow out and have many cracks, which can occur often in polar regions. Under such conditions, some stages in Fig. 12 might duplicate and proceed simultaneously.

\section{Concluding remarks}

Simultaneous sampling and observations of frost flowers, brine, and atmospheric aerosol particles were conducted around Siorapaluk, northwestern Greenland at the end of December 2013 to March 2014. We obtained the following direct evidence from our field observations: (1) presence of ikaite-like particles, mirabilite-like particles, and sea-salt particles with ratios similar to seawater in the atmosphere at new sea-ice areas (sites IIIa and IIIb); (2) changes in seasalt ratios of frost flowers by sea-salt fractionation such as mirabilite and hydrohalite precipitation at site I; (3) seasalt enrichment in frost flowers and surface snow; (4) presence of Mg-rich sea-salt particles and $\mathrm{Mg}$-salt particles in the atmosphere; (5) higher $\mathrm{Mg} / \mathrm{Na}$ ratio in aerosol particles in fine mode; (6) small variation of the $\mathrm{Mg} / \mathrm{Na}$ ratio in aerosols under conditions with strong winds and blowing snow; and (7) $\mathrm{Mg}$ depletion in the aged surface snow on sea ice. From this evidence and results from earlier investigations, we proposed sea-salt cycles in seasonal sea-ice area during the winter. At the moment, some processes are inferred from our field evidence. In addition to analysis of frost flowers, brine, and snow, more field studies and laboratory experiments must be applied to aging frost flowers, seasalt fractionation, the release of fractionated sea salts into the atmosphere, and halogen chemistry in polar regions.

Data availability. The data in this this paper are available from the authors upon request. Please contact the corresponding author, Keiichiro Hara (harakei@fukuoka-u.ac.jp).

The Supplement related to this article is available online at https://doi.org/10.5194/acp-17-8577-2017-supplement.

Competing interests. The authors declare that they have no conflict of interest.

Acknowledgements. We thank Ikuo Oshima and Siorapaluk residents for extremely useful comments and help related to operations on sea ice, sea-ice conditions, and the appearance of frost flowers. This study was supported by a Grant-in-Aid for Challenging Exploratory Research (PI: Keiichiro Hara, No. 25550018).

Edited by: Sergey A. Nizkorodov

Reviewed by: Howard K. Roscoe, Florent Dominé, and one anonymous referee 


\section{References}

Abbatt, J. P. D., Thomas, J. L., Abrahamsson, K., Boxe, C., Granfors, A., Jones, A. E., King, M. D., Saiz-Lopez, A., Shepson, P. B., Sodeau, J., Toohey, D. W., Toubin, C., von Glasow, R., Wren, S. N., and Yang, X.: Halogen activation via interactions with environmental ice and snow in the polar lower troposphere and other regions, Atmos. Chem. Phys., 12, 6237-6271, https://doi.org/10.5194/acp-12-6237-2012, 2012.

Alvarez-Aviles, L., Simpson, W., Douglas, T., Sturm, M., Perovich, D., and Domine, F.: Frost flower chemical composition during growth and its implications for aerosol production and bromine activation, J. Geophys. Res., 113, D21304, https://doi.org/10.1029/2008JD010277, 2008.

Barrie, L. A., Bottenheim, J. W., Schnell, R. C., and Crutzen, P. J.: Ozone destruction and photochemical reactions at polar sunrise in the lower Arctic atmosphere, Nature, 334, 138-141, https://doi.org/10.1038/334138a0, 1988.

Brandt, R. E., Warren, S. G., Worby, A. P., Grenfell, T. C., Brandt, R. E., Warren, S. G., Worby, A. P., and Grenfell, T. C.: Surface Albedo of the Antarctic Sea Ice Zone,Surface Albedo of the Antarctic Sea Ice Zone, J. Climate, 18, 3606-3622, https://doi.org/10.1175/JCLI3489.1,10.1175/JCLI3489.1, 2005.

Chen, Z., Megharaj, M., and Naidu, R.: Speciation of iodate and iodide in seawater by non-suppressed ion chromatography with inductively coupled plasma mass spectrometry, Talanta, 72, 18421846, https://doi.org/10.1016/j.talanta.2007.02.014, 2007.

Comiso, J. C.: Fundamental of characteristics of the Polar oceans and their sea-ice cover, in: Polar oceans from space, Springer, 19-71, 2010.

Comiso, J. C. and Steffen, K.: Studies of Antarctic sea ice concentrations from satellite data and their applications, J. Geophys. Res., 106, 31361-31385, https://doi.org/10.1029/2001JC000823, 2001.

DeMott, P. J., Hill, T. C. J., McCluskey, C. S., Prather, K. A., Collins, D. B., Sullivan, R. C., Ruppel, M. J., Mason, R. H., Irish, V. E., Lee, T., Hwang, C. Y ., Rhee, T. S., Snider, J. R., McMeeking, G. R., Dhaniyala, S., Lewis, E. R., Wentzell, J. J. B., Abbatt, J., Lee, C., Sultana, C. M., Ault, A. P., Axson, J. L., Martinez, M. D., Venero, I., Santos-Figueroa, G., Stokes, M. D., Deane, G. B., Mayol-Bracero, O. L., Grassian, V. H., Bertram, T. H., Bertram, A. K., Moffett, B. F., and Franc, G. D.: Sea spray aerosol as a unique source of ice nucleating particles, P. Natl. Acad. Sci. USA, 113, 5797-5803, https://doi.org/10.1073/pnas.1514034112, 2016.

Dieckmann, G. S., Nehrke, G., Papadimitriou, S., Göttlicher, J., Steininger, R., Kennedy, H., Wolf-Gladrow, D., and Thomas, D. N.: Calcium carbonate as ikaite crystals in Antarctic sea ice, Geophys. Res. Lett., 35, L08501, https://doi.org/10.1029/2008GL033540, 2008.

Dieckmann, G. S., Nehrke, G., Uhlig, C., Göttlicher, J., Gerland, S., Granskog, M. A., and Thomas, D. N.: Brief Communication: Ikaite $\left(\mathrm{CaCO}_{3} \cdot 6 \mathrm{H}_{2} \mathrm{O}\right)$ discovered in Arctic sea ice, The Cryosphere, 4, 227-230, https://doi.org/10.5194/tc-4-227-2010, 2010

Domine, F., Taillandier, A., Simpson, W., and Severin, K.: Specific surface area, density and microstructure of frost flowers, Geophys. Res. Lett., 32, L13502, https://doi.org/10.1029/2005GL023245, 2005.
Douglas, T., Domine, F., Barret, M., Anastasio, C., Beine, H., Bottenheim, J., Grannas, A., Houdier, S., Netcheva, S., Rowland, G., Staebler, R., and Steffen, A.: Frost flowers growing in the Arctic Ocean - atmosphere - sea ice - snow interface: 1. Chemical composition, J. Geophys. Res., 117, L13502, https://doi.org/10.1029/2011JD016460, 2012.

Ebinghaus, R., Kock, H., Temme, C., Einax, J., Löwe, A., Richter, A., Burrows, J., and Schroeder, W.: Antarctic Springtime Depletion of Atmospheric Mercury, Environ. Sci. Technol., 36, 12381244, https://doi.org/10.1021/es015710z, 2002.

Foster, K. L., Plastridge, R. A., Bottenheim, J. W., Shepson, P. B., Finlayson-Pitts, B. J., and Spicer, C. W.: The role of $\mathrm{Br} 2$ and $\mathrm{BrCl}$ in surface ozone destruction at polar sunrise, Science, 291, 471-474, https://doi.org/10.1126/science.291.5503.471, 2001.

Geilfus, N.-X., Galley, R., Cooper, M., Halden, N., Hare, A., Wang, F., Søgaard, D., and Rysgaard, S.: Gypsum crystals observed in experimental and natural sea ice, Geophys. Res. Lett., 40, 6362 6367, https://doi.org/10.1002/2013GL058479, 2013.

Hara, K., Osada, K., Nishita, C., Yamagata, S., Yamanocuhi, T., Herber, A., Matsunaga, K., Iwasaka, Y., Nagatani M., and Nakata, H.: Vertical variations of sea-salt modification in the boundary layer of spring Arctic during the ASTAR 2000 campaign, Tellus B, 54, 361-376, https://doi.org/10.1034/j.16000889.2002.201253.x, 2002.

Hara, K., Yamagata, S., Yamanouchi, T., Sato, K., Herber, A., Iwasaka, Y., Nagatani, M., and Nakata, H.: Mixing states of individual aerosol particles in spring Arctic troposphere during ASTAR 2000 campaign, J. Geophys. Res. 108, 4209, https://doi.org/10.1029/2002JD002513, 2003.

Hara, K., Osada, K., Kido, M., Hayashi, M., Matsunaga, K., Iwasaka, Y., Yamanouchi, T., Hashida, G., and Fukatsu, T.: Chemistry of sea-salt particles and inorganic halogen species in Antarctic regions: Compositional differences between coastal and inland stations, J. Geophys. Res., 109, D20208, https://doi.org/10.1029/2004JD004713, 2004.

Hara, K., Osada, K., Kido, M., Matsunaga, K., Iwasaka, Y., Hashida, G., and Yamanouchi, T.: Variations of constituents of individual sea-salt particles at Syowa Station, Antarctica, Tellus B, 57, 230-246, https://doi.org/10.1111/j.16000889.2005.00142.x, 2005.

Hara, K., Osada, K., Yabuki, M., Hashida, G., Yamanouchi, T., Hayashi, M., Shiobara, M., Nishita, C., and Wada, M. Haze episodes at Syowa Station, coastal Antarctica: Where did they come from?, J. Geophys. Res., 115, D14205, https://doi.org/10.1029/2009JD012582, 2010.

Hara, K., Osada, K., Nishita-Hara, C., Yabuki, M., Hayashi, M., Yamanouchi, T., Wada, M., and Shiobara, M.: Seasonal features of ultrafine particle volatility in the coastal Antarctic troposphere, Atmos. Chem. Phys., 11, 9803-9812, https://doi.org/10.5194/acp-11-9803-2011, 2011.

Hara, K., Osada, K., Yabuki, M., and Yamanouchi, T.: Seasonal variation of fractionated sea-salt particles on the Antarctic coast, Geophys. Res. Lett., 39, L18801, https://doi.org/10.1029/2012GL052761, 2012.

Hara, K., Osada, K., and Yamanouchi, T.: Tethered balloonborne aerosol measurements: seasonal and vertical variations of aerosol constituents over Syowa Station, Antarctica, Atmos. Chem. Phys., 13, 9119-9139, https://doi.org/10.5194/acp-139119-2013, 2013. 
Hara, K., Nakazawa, F., Fujita, S., Fukui, K., Enomoto, H., and Sugiyama, S.: Horizontal distributions of aerosol constituents and their mixing states in Antarctica during the JASE traverse, Atmos. Chem. Phys., 14, 10211-10230, https://doi.org/10.5194/acp-14-10211-2014, 2014.

Hirokawa, T., Ichihara, T., Ito, K., and Timerbaev, A.: Trace ion analysis of seawater by capillary electrophoresis: determination of iodide using transient isotachophoretic preconcentration, Electrophoresis, 24, 2328-2334, https://doi.org/10.1002/elps.200305445, 2003.

Horikawa, Y., Kusumoto, R., Yamane, K., Nomura, R., Hirokawa, T., and Ito, K.: Determination of Inorganic Anions in Seawater Samples by Ion Chromatography with Ultraviolet Detection Using Monolithic Octadecylsilyl Columns Coated with Dodecylammonium Cation, Anal. Sci., 32, 1123-1128, https://doi.org/10.2116/analsci.32.1123, 2016.

Ito, K.: Determination of Iodide in Seawater by Ion Chromatography, Anal. Chem., 69, 3628-3632, https://doi.org/10.1021/ac9700787, 1997.

Ito, K.: Semi-micro ion chromatography of iodide in seawater, J. Chromatogr. A, 830, 211-217, https://doi.org/10.1016/S00219673(98)00910-8, 1999.

Ito, K., Ichihara, T., Zhuo, H., Kumamoto, K., Timerbaev, A., and Hirokawa, T.: Determination of trace iodide in seawater by capillary electrophoresis following transient isotachophoretic preconcentration Comparison with ion chromatography, Anal. Chim. Acta, 497, 67-74, https://doi.org/10.1016/j.aca.2003.08.052, 2003.

Kaleschke, L., Richter, A., Burrows, J., Afe, O., Heygster, G., Notholt, J., Rankin, A., Roscoe, H., Hollwedel, J., Wagner, T., and Jacobi, H. W.: Frost flowers on sea ice as a source of sea salt and their influence on tropospheric halogen chemistry, Geophys. Res. Lett., 31, L16114, https://doi.org/10.1029/2004GL020655, 2004

Keene, W., Maring, H., Maben, J., Kieber, D., Pszenny, A., Dahl, E., Izaguirre, M., Davis, A., Long, M., Zhou, X., Smoydzin, L., and Sander, R.: Chemical and physical characteristics of nascent aerosols produced by bursting bubbles at a model air-sea interface, J. Geophys. Res., 112, D21202, https://doi.org/10.1029/2007JD008464, 2007.

Kelly, J. and Wexler, A.: Thermodynamics of carbonates and hydrates related to heterogeneous reactions involving mineral aerosol, J. Geophys. Res., 110, D11201, https://doi.org/10.1029/2004JD005583, 2005.

Koop, T., Kapilashrami, A., Molina, L., and Molina, M.: Phase transitions of sea-salt/water mixtures at low temperatures: Implications for ozone chemistry in the polar marine boundary layer, J. Geophys. Res., 105, 26393, https://doi.org/10.1029/2000JD900413, 2000.

Lewis, E. R. and Schwartz, S. E.: Measurements and Models of Quantities Required to Evaluate Sea Salt Aerosol Production Fluxes, Sea Salt Aerosol Production: Mechanisms, Methods, Measurements and Models, American Geophysical Union, 119297, 2004.

Lide, D. R.: Handbook of Chemistry and Physics, 86th Edn., 2005.

Lieb-Lappen, R. M. and Obbard, R. W.: The role of blowing snow in the activation of bromine over first-year Antarctic sea ice, Atmos. Chem. Phys., 15, 7537-7545, https://doi.org/10.5194/acp15-7537-2015, 2015.
Marion, G., Farren, R., and Komrowski, A.: Alternative pathways for seawater freezing, Cold Reg. Sci. Technol., 29, 259-266, https://doi.org/10.1016/S0165-232X(99)00033-6, 1999.

Martin, S., Drucker, R., and Fort, M.: A laboratory study of frost flower growth on the surface of young sea ice, J. Geophys. Res.Oceans, 100, 7027-7035, https://doi.org/10.1029/94JC03243, 1995.

Martin, S., Yu, Y., and Drucker, R.: The temperature dependence of frost flower growth on laboratory sea ice and the effect of the flowers on infrared observations of the surface, J. Geophys. Res.Oceans, 101, 12111-12125, https://doi.org/10.1029/96JC00208, 1996.

Millero, F.: Compositions of the major components of seawater, in: Chemical Oceanography, 4th Edn., 55-89, CRC Press, 2016.

Millero, F., Feistel, R., Wright, D., and McDougall, T.: The composition of Standard Seawater and the definition of the ReferenceComposition Salinity Scale, Deep-Sea Res. Pt. I, 55, 50-72, https://doi.org/10.1016/j.dsr.2007.10.001, 2008.

Obbard, R., Roscoe, H., Wolff, E., and Atkinson, H.: Frost flower surface area and chemistry as a function of salinity and temperature, J. Geophys. Res., 114, D20305, https://doi.org/10.1029/2009JD012481, 2009.

Perovich, D. and Richter-Menge, J.: Surface characteristics of lead ice, J. Geophys. Res.-Oceans, 99, 16341-16350, https://doi.org/10.1029/94JC01194, 1994.

Rankin, A., Auld, V., and Wolff, E.: Frost flowers as a source of fractionated sea salt aerosol in the polar regions, Geophys. Res. Lett., 27, 3469-3472, https://doi.org/10.1029/2000GL011771, 2000.

Rankin, A., Wolff, E., and Martin, S.: Frost flowers: Implications for tropospheric chemistry and ice core interpretation, J. Geophys Res., 107, 4683, https://doi.org/10.1029/2002JD002492, 2002.

Roscoe, H., Brooks, B., Jackson, A., Smith, M., Walker, S., Obbard, R., and Wolff, E.: Frost flowers in the laboratory: Growth, characteristics, aerosol, and the underlying sea ice, J. Geophys. Res., 116, D12301, https://doi.org/10.1029/2010JD015144, 2011.

Schroeder, W. H., Anlauf, K. G., Barrie, L. A., Lu, J. Y., and Steffen, A.: Arctic springtime depletion of mercury, Nature, 394, 331332, 1998.

Style, R. and Worster, M.: Frost flower formation on sea ice and lake ice, Geophys. Res. Lett., 36, L11501, https://doi.org/10.1029/2009GL037304, 2009.

Twohy, C. H. and Poellot, M. R.: Chemical characteristics of ice residual nuclei in anvil cirrus clouds: evidence for homogeneous and heterogeneous ice formation, Atmos. Chem. Phys., 5, 22892297, https://doi.org/10.5194/acp-5-2289-2005, 2005.

Udisti, R., Dayan U., Becagli S., Busetto M., Frosini D., Legrand M., Lucarelli F., Preunkert S., Severi M., Traversi R., and Vitale V.: Sea spray aerosol in central Antarctica. Present atmospheric behaviour and implications for paleoclimatic reconstructions, Atmos. Environ., 52, 109-120, 2012.

Wagenbach, D., Ducroz, F., Mulvaney, R., Keck, L., Minikin, A., Legrand, M., Hall, J., and Wolff, E.: Sea-salt aerosol in coastal Antarctic regions, J. Geophys. Res., 103, 10961-10974, https://doi.org/10.1029/97JD01804, 1998.

Wise, M. E., Baustian, K. J., Koop, T., Freedman, M. A., Jensen, E. J., and Tolbert, M. A.: Depositional ice nucleation onto crystalline hydrated $\mathrm{NaCl}$ particles: a new mechanism for ice formation in the troposphere, Atmos. Chem. Phys., 12, 1121-1134, https://doi.org/10.5194/acp-12-1121-2012, 2012. 
Wolff, E., Rankin, A. M., and Röthlisberger, R.: An ice core indicator of Antarctic sea ice production, Geophys. Res. Lett., 30, 2158, https://doi.org/10.1029/2003GL018454, 2003.

Wolff, E., Fischer, H., Fundel, F., Ruth, U., Twarloh, B., Littot, G., Mulvaney, R., Röthlisberger, R., de Angelis, M., Boutron, C., Hansson, M., Jonsell, U., Hutterli, M., Lambert, F., Kaufmann, P., Stauffer, B., Stocker, T., Steffensen, J., Bigler, M., Siggaard-Andersen, M., Udisti, R., Becagli, S., Castellano, E., Severi, M., Wagenbach, D., Barbante, C., Gabrielli, P., and Gaspari, V.: Southern Ocean sea-ice extent, productivity and iron flux over the past eight glacial cycles, Nature, 440, 491-496, https://doi.org/10.1038/nature04614, 2006.
Yang, X., Pyle, J. A., Cox, R. A., Theys, N., and Van Roozendael, M.: Snow-sourced bromine and its implications for polar tropospheric ozone, Atmos. Chem. Phys., 10, 7763-7773, https://doi.org/10.5194/acp-10-7763-2010, 2010. 